University of Louisville

ThinkIR: The University of Louisville's Institutional Repository

Electronic Theses and Dissertations

1947

\title{
Heat sealing properties of ethyl cellulose modified lacquers.
}

William B. Moore 1924-2015

University of Louisville

Follow this and additional works at: https://ir.library.louisville.edu/etd

Part of the Chemical Engineering Commons

\section{Recommended Citation}

Moore, William B. 1924-2015, "Heat sealing properties of ethyl cellulose modified lacquers." (1947).

Electronic Theses and Dissertations. Paper 2058.

https://doi.org/10.18297/etd/2058

This Master's Thesis is brought to you for free and open access by ThinkIR: The University of Louisville's Institutional Repository. It has been accepted for inclusion in Electronic Theses and Dissertations by an authorized administrator of ThinkIR: The University of Louisville's Institutional Repository. This title appears here courtesy of the author, who has retained all other copyrights. For more information, please contact thinkir@louisville.edu. 


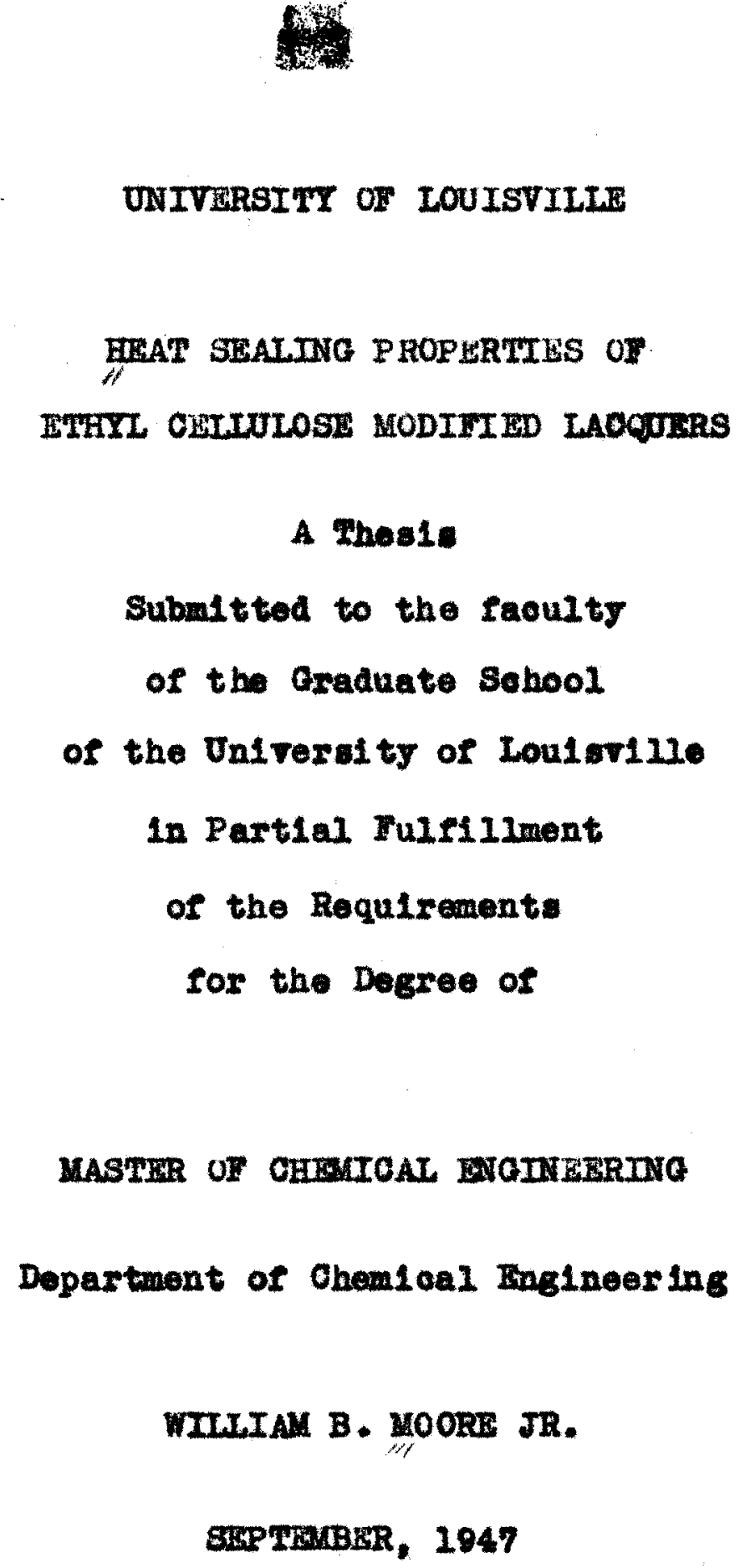

MASTER OR CHEMICAL EVTHEERTIG

Department of Chemloal Sogineering

WIILIAM B. MOORE JR. SEPTRABER, 1947 


\section{UNIVERSITY}

LIBRARIES

This PDF document is a scanned copy of a paper manuscript housed in the University of Louisville (UofL) Libraries. The quality of this reproduction is greatly dependent upon the condition of the original paper copy. Indistinct print and poor quality illustrations are a direct reflection of the quality of materials that are available for scanning. The UofL Libraries greatly appreciates any better copies that can be made available for replacement scans. 
BKAT SEALINO PROP BRTTES OF

ETHYL CELLULOSI MODIFIED LACQUERS

WILLIAM B. NOORE JR.

Approved by the lixamining Comalteo.

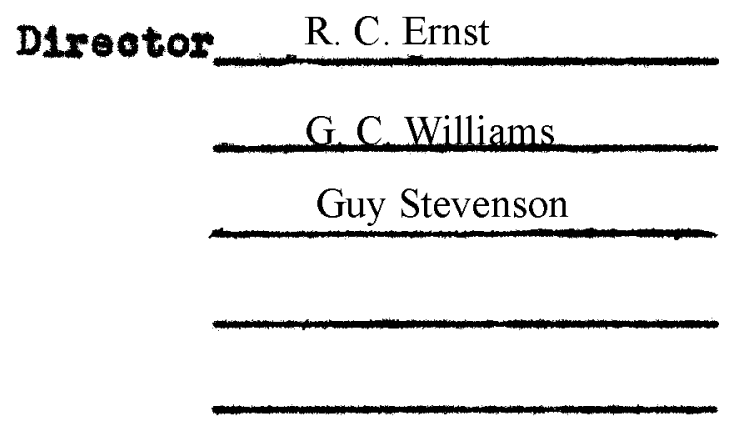

SEPTRMBRR, 1947 
courumas

Page

I1st of Tables $\ldots \ldots \ldots \ldots \ldots \ldots \ldots \ldots \ldots$ 17

Lst or ILures $\ldots \ldots \ldots \ldots \ldots \ldots \ldots \ldots \ldots \ldots$ v

Aaknowledgenont $\ldots \ldots \ldots \ldots \ldots \ldots \ldots \ldots \ldots \ldots \ldots . \quad \mathbf{1 1}$

Abetract ....................... $\mathbf{1 1 1}$

Introduotion $\ldots \ldots \ldots \ldots \ldots \ldots \ldots \ldots \ldots \ldots$

Blstor1eal $\ldots \ldots \ldots \ldots \ldots \ldots \ldots \ldots \ldots \ldots \ldots \ldots$

Theoret1eal .................... Is

Experimental .....................

Coms1un1one $\ldots \ldots \ldots \ldots \ldots \ldots \ldots \ldots \ldots \ldots \ldots$

L teratume o1ted ............... 62

Aoknowledgenent $\ldots \ldots \ldots \ldots \ldots \ldots \ldots \ldots \ldots \ldots .66$

Appond1x $\ldots \ldots \ldots \ldots \ldots \ldots \ldots \ldots \ldots \ldots \ldots \ldots . \ldots 67 \ldots$

V1ta $\ldots \ldots \ldots \ldots \ldots \ldots \ldots \ldots \ldots \ldots \ldots \ldots \ldots \ldots \ldots 6,69$ 


\section{IISI OE TABLPB}

I. Aabsion, Blocking, and Floxiblilty Characteriation of the Formulation of each Bystem Bent Comblning These Properties .............. 58

II. Adhesion, Blokelng, and Floxibility Charaoteristles of the System Ithyl Collulose-Arochlor 1262

III. Aabeston, Blook Ing, and Flexibility CharaoterIst1os of the System Ethyl Celluloae-Dow Plastlokzer No. $6 \ldots \ldots \ldots \ldots \ldots \ldots \ldots \ldots \ldots \ldots \ldots \ldots \ldots$

IV. Adhealon, Blook1ng, and Flexiblilty Charaoter1stlos of the System sthyl Cellulose-Bakellte 14967

7. Materials to Whl oh Formulations HS-148 and HS-196 Wore Bealed

vI. Comparison Between Cork Mpping Beams Made HS-148 and Thowe Made With the Rogular Industrial

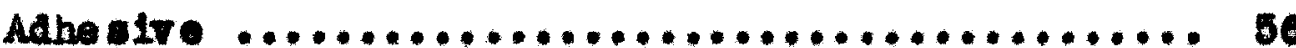


LIST OF FICURES

Page

2. The Rereet of Ithoxy Content on the Melting Point of rilms of Pure Ethyl Cellulow ............... 19

2. Melting Point Diagram for the syatem Bthyl

Cellulose-Amberol Fq ........................ 21

3. Plotting a Inequer Composition on a Three Component Dlagran ................................. 28

4. Defining the Area of Laoquer Compositions That Pass the Flexib111ty Teat ..................... 2s

5. Derlning The Area of Inequer Ocapositions That Have Cold Chook Realatance .................... 28

6. Defining The Area of Laoquer Compositions Whloh are Print Roslatant ........................ 28

7. Canting F1lm of Ethyl Collulose .............. 29

o. Teating Ithri Cellulose Films on the Soott F1lm Tostex .................................. 29

9. Teatlng Ithyl Celiulose F1lme by the Penoll Test . 20

10. Po1l Laminate Used in Brown-Williamson Heat Bealing Paokager ............................. 35

11. Dlexiblilty Charaoteristios of the Syatem Bthyl Cellulose-Nevillao S-Aroohlor 2862 ............ 36

12. Blooking Charaoterieties of the System Bthyl Cellulose-Herillad S-Aroohlor $1262 \ldots \ldots \ldots \ldots . . .39$ 
13. Adhesion Charaoteristios of the Syatem Ithyl Cellulose-Nevillao S-Aroohlor $1262 \ldots . . . \ldots \ldots . .38$

14. Adhesion, Blooking, and Flexiblilty Characteristios of the system Ethyl Cellulose-Ner1llao S-Arochlor $1262 \ldots \ldots \ldots \ldots \ldots \ldots \ldots \ldots \ldots \ldots \ldots \ldots \ldots \ldots \ldots \ldots \ldots \ldots$

15. Adhesion, Blooking, and Compatibility Charaoter1st10s of the System Ethyl Cellulose-Dow Resin 276 VZ-Tr10resyl Phosphate

16. Adhesion, Blooking, and Compatibility CharaoterIat1es of the Syetem Bthyl Cellulose-Dow Rouln 276 V2-Dow Plastlelzer No. 5 ...................... 42

17. Adhesion, Floxiblilty, and Blooking Oharaoteristioa of the Syatem Bthyl Cellulose-Poly Pale ResinBakellte XJ 15830 ..........................

18. Blooking and Flexiblilty Characteristios of the Syotem Ethyl Collulose-Super Beokac1te 1001-Dow Plastlolzer No. 6

19. Adheslon and Blook1ng Charaoteristlos of the System Ethyl Collulose-Ros in WW-TrLoresyl Phoaphate ..... 45

20. Blooking and Flexiblilty Charaeteristlos of the Systen Ethyl Collulose-Bakel1 to BR 254-Dow Plast1olzer Ho. $6 . \ldots \ldots \ldots \ldots \ldots \ldots \ldots \ldots \ldots \ldots \ldots \ldots \ldots \ldots \ldots \ldots . . . \ldots 46$

21. Adhosion and Blooking Oharateristios of the Syetem Ethyl Cellulose-3taybel1 to Realn-Trioreayl Phosphato 
The author whes to aoknowledge

the klnd assistanoe and helpful guldanoe

of Dr. R. C. Ernst,

who direoted this researoh 
$\nabla 111$

ABSTRACI 
The heat sealing properties of lacquers contalning ethyloellulose were studied. Adheslon, blook, flexiblilty, and appearance were consldered to be the properties most important in determining the usefulness of a heat sealing agent.

The experimental procedure onsisted in the formulation and testing of various laoquer systems. Data from these systems are presented in the form of areas on triangular composition plots.

Two laoquers, is 148 and 185 196, fulfilled the problem requirements. The compositions of these laoquers are

HS 148

ethyloellulose.........55.0\% ethyleellulose.

Dow resin 276-V2....... 30.0 Dow resin 276-V2.......40.0 trioreayl phosphate..... 14.7 Dow plastiolzer No. 5... 14.7 carnauba wax........... 0.3 carnauba wax......... 0.3

HS 148 samples have been applied on Industrial hoat sealing meohinery. The seals made in this manner compare favorably whth those produced on the same maohines with normally accepted induetrlel laoquers. Hs 196 produoes seala slightly inferlor to those of 15 148. It is reoommended for use in handling roods, howerer, as it has no deteotable toxla1ty. 
INTRODUCTION 
This Inrestigation is a study of the bonding charaoteristlos of IIIms contalning ethyloellulose. Adhosive are usually olassteled as animal derivative, vegetable derivative, cellulose derlvative, or synthet1o. Animal glues, usually cold 11quids, are composed of liquid extracts from the bones, skins, and hoofs of anlmals. Casein adhesives, made from a product of the coagulation of milk, are al so olassifled as of animal oribin. Animal glues are general purpose adhesives which produce medium strength bonds between many different materials.

The term regetable adhesive inoludes gum emulsions, dextrin adhesives, latex oementa, natural resin adhesives. Gum adhes1res, consisting of aqueous emulsions of natural gums, such as arablo, are used for choap, low strength bonding. Dextrin glues are prepared from a produet of the degradation of staroh at higher temperatures. When molsture resistanoe is unimportant dextrin-base adhesives form good bonds between wood, paper, and similar substanees. Rubber latex is the cured milk sap of the rubber tree or quauale shrub. An extremely stloky substance, latex has found wide usage in general purpose bonding. Shellacs and rosins are used elther alone or with added compounds to form many ahesires. Their use is similar to that of synthetio resins in adhesires. The prinolpal app11cation of natural rosing is in mixtures ontaining other 
regetable or synthetio materiala. Cellulose derivative laequers are widely used to replace both rubber cements and animal glues, Elther as pure substanoes or mixed with plast1olzers and resins, cellulose derivatives are dis solved in sultable solvents and applied as oold 11quids. Nelted from solla form, cellulose derivatives are called "hot molts". The derivatives most oommon to soating and adhesire applicatlons are nitro collulose, cellulose acotate, and ethyl collulose. Cellulose derivatives may be made to fom strong water-resistant bonds. They are, however, affeoted by hoat, organio solvents, and, in some cases, 11ght.

Synthet10 adhesives are too numerous and varied in form to be disoussed individually. Synthetio ocmpounds have been made whose properties duplloate and surpass those of many natural adhesives. A large majorlty of these synthetios are phenolle, urea, aoryl10, or vingl in nature. The application of synthetio adhesives is for strong, permanentig resistant bonds.

Aahesives are applied in several ways. The oldest and most common consists of brushing a liquid adhesive material on one or both surfaces to be joined and holding the oceted surfaoes together unt1l the Ilquid has arled or set. In many cases heat is applied to speed up the drying or setting operation. Although liquid appliation is often accomplishod 
by machine brushes, relle, or dootor knires, the prinolple rema1ns unchanged.

The so called dry method (1) consists of coating 11quid adhesives on the surfaces to be bonded. After drying the coated surface, bonding is obtained by means of heat and pressure. Both thermoplastio and thermosetting adhogives can be handled in this manner. Although sereral other means of applying adhesives are used, the liquid and ary prinolples cover the majority of present day techniques.

Industries using adhesives on a large scale are numerous and wide spread. Wood fabrioation and paokaging can be chosen as representative of those users. Aside from the manufacture of oheap toys, novelties, and varlous low strength articles, the fabrication of wood demands hligh strength adhesives. The manufacture of plywood furnlture and prefabrieated wooden parts requires durable bonds that w11 strengthen rather than weaken the final produot. Synthetic thermosetting resin adhesives are, therefore, best sulted to wood fabrication. The two adhesires most common to that Industry are phenol and urea formaldehydes. Both glues of phenol and urea, like most thermosetting adhesires, must be bonded under heat and pressures. Curing requires from one second to four hours, and heated presses are many times sul ted to industrles employing the rmosetting adhesives. 
The paokaging industry used some form of each adhesive olassfiled. Bonding metal folls, papers, plastios, and cardboards requires many glues and techniques. The flimsy, temporary nature of products from the paokaging industry make high bond strengths unnecessary; therefore there is limited use for the hlgh trength synthetics used for wood bonding.

Until recently, all packaging operations used liquid anlmal or vegetable glue. Those glues still predominate in that field. In the last fifteen years, however, the dry method of adhealve application has beoome more acoeptable. In order to inorease production speed and eliminate the handling of liquid glues, bonds are made by sealing certain thermoplast10 films under heat and pressure. That process is known as heat-sealing. Adhesives or heat sealing agents are coated on the material to be bonded. The coated foll or paper can then be sealed or packed for distribution to other sealing operations.

Heat sealing agents are thermoplastio materials whioh require only instantaneous applloations of heat and pressure for bond ing. Continuous rapld sealing processes oan therefore be used. The high sealing speods and almost immediate setting of the bond after sealing makes heat sealing a prooess readily adapted to the packaging industry. Heated rolls, metal tapes, 
Irons, wheels, and presses are all ut1lized to form heat seals. Heat sealing films are classifled by means of the constituent present in the highest ooncentration. Classifled in that way, most heat sealing agents are elther wax, rubber, resin, or cellulose derivative adhesives. Adhesives of each type almost Invariably contain one of the other named const1tuents. Many contain all of them.

Wax coatings have been used for heat sealing more than have the other types. Paraffin coatings, beeswax films, carnauba hot melts, and other mlorocrystalline wares have been sealed by means of heat for many years. The use of wax to seal letters dates back to the Roman Inpire. Bonds of wax sealed coatings are, at best, of low strength. Wax seals are used prodominantly for applications where molsture resistance, not strength, controls.

Rubber and resin oompounds have not been widely used as heat sealing agents. Both are frequently found in heat sealing lacquers as modifying agents, but seldom are they present in amounts orer 25 per oent. Rubber derivative adhesires are soft and stloky or taoky at relatively low temperatures. That property $11 \mathrm{mlts}$ the use of rubber in lacquers whloh must be non-tacky for shlpment and storage. properly formulated cellulose derivative laoquers offer the non-taokiness of wax at low temperatures and 
satisfactory adhesion at elevated temperatures. Mitrocellulose, ethyloellulose, and oellulose aoetate all have the rmal properties suited to the temperature and pressure requirements of heat sealing. Bthylcellulose, of the three, is reoognized as the best material for heat sealing (2).

A heat sealing agent for the paokaging industry must meet several speoiflcations. The first and most important Is that the terial produce satisfactory bonds at the speoifled temperatures. In arder that rolls of foll or peper coated with such a flim can be stored the laoquer must not be stioky or taky at ordinary storage temperatures. To adhere to the folls and papers used in the paokaging industry the fllm must be flexible. It is of partioular importanoe to the rood packager that compound used in connection with edibles be free from taste, odor, and toxiolty.

The work desoribed in the following thesis is an attempt to formulate a heat sealing agent with ethylcellulose as a major constituent. The coating was to be applied as a liquid and dried before sealing. Under minimum pressure it was to seal at temperatures from 120 to $1600 \mathrm{C}$, to aluminum foll, glassene paper (3), oellophane, fllms of the laoquer 1tself, and other related substanoes. The f1lm was to be tack-free after 24 hours exposure to $500 \mathrm{c}$. under one pound per square inch. It could have no taste, odor, or toxiolty. 
It must be flexible and sufted to standard means of application. 
ATSTORICAT. 
The use of thermoplastlo wares for the sealing of letters and private papers was, probably, the first distinot heat sealing operation (4). Seals of that type have been found among rellos of anolent sigpt.

Heat sealing has not, unt1l recentiy, had a separate place in the fleld of adhealon. The use of heat and pressure to ald drying or setting of Ilquid glues was, of course, a common praotice; that practioe, however, cannot be termed heat sealing. It is purely a means by whioh the 11quid seal ing oyeration is aped up and improved. Work with hot melt coatings led to the development of heat sealing agent: for industrial operations, R. Gordan (5) was among the firgt to recognize the use of ethyl cellulose hot melt coatings and their use as adhesives. He introduced a ooating oontaining ethyloellulose and latex to be applied in molted form. The f1lm was quite tacky and therefore not sulted to storage on rolls or in packages.

Staundinger $(6)$ and Henkle $(7,8)$, olosely following Gordan, patented hot melt coatings in 1938 and 1939. The coatings patented by Staundinger and the two by Henkle differed but elightly. Both contalned ethyloellulose, staroh, and some polymer. Coatlings of this type polymertze on belng applied as hot melts and have no further applioation as heat sealing agents, 
The most signifioant patents on hot melt and heat sealing compounds is sued in 1939-1940 were to Bidald and Farre (9), Nobel (10) and C. E. PItman (11). Those patents covered three phase formulations of thylcellulose, resin, and plast1olzer. The films of Bidald and Farre an Nobel were hot me it adhesives. That of Pitman was designed to be applied in melted form or from solvent solution. Mr. Pltman also olaimed that flims, when formulated according to his specifloations, when plaoed together will seal under silght addition of heat. I. Q. Farben and Company (12), also in 1914, referred to a laoquer having properties similar to those developed by P1tman. They did not, however, give any indication of the content of this material.

S1x petents were issued in 1942-43 for heat sealing agents. The patent to Ryan and Watkins (13) covered the use or oellulose sheeting in the lamination of glass for shatterproof automoblie windows. The glass plates and separating ethyloellulose sheeting are bonded by means of heat and pressure. A plastlalzer is added to the othyloellulose sheeting to lower its melting temperature. Both Kauppe (14) and Thinlus (15) obtalned patents for films to be heat sealed to tin and lead folls. Baoh contalned ethylcellulose, phosphorlo aold, and a plastlolzer. W. J. Barrow (16) developed a flim composed of ethylcellulose and a plastlofizer to 
preserve old parohments. The parohments are coated by hot pressing the ethylcellulose film to the surface to be coated. Temperatures of less than 100 degrees $\mathrm{C}$. are used in the prooess. Alexander Szware (17) a Canadian, and John M. DeBell (18), an Englighman, patented, almost simultaneously, heat sealing agents that today are widely used in the packaging industry. The two lacquers differ in both composition and plastiolzer. They are, however, of the same three component type, containing thyloellulose, pine wood rosin, and a plastiolzer. Lelnbach (19), in 1943, made a substantial 11terary contribution to the theory and practice of heat-sealing. Mr. Lelnbach disoussed both heat-sealing and heat sealling agents. His major contribution was in proposing certain specifications for the standardization of the evaluation tests of heat sealing lacquers. Mr. Leinbach defined heat sealing only from the standpoint of sealing film to films of the same material.

A paper by Binner and Miller (20), in 1944, broadened Leinbach's definftion to inolude sealing a thermoplastio film to any other material. The paper also disoussed the process of laminating folls and papers by means of heat sealing methods.

The fleld of patents on ethylcellulose containing heat sealing agents was very broad in 1944. Among those recelving most attention were patents to Collins (21), Kooh (22), Robinson (23), Baoon (24), and Haok (25), Collins 
clalmed an ethylcellulose flim for laminating plastios sultable for use as phonograph records. The film hes a high melting temperature and strong resistano to cold flow. Kooh, Robinson, Bacon, and Mack all patented three somponent ethyloellulose heat sealing laoquers. Tach of those agenta was designed for the bonding of paokaging papers.

The year 1845 produced only two heat sealing agents containing ethyloellulose. In the first, Rhodes and Wendore (26) perfected an ethyloollulose wax comblnation for use in paper sealing prooesses. The objeot of this combination is to produce heat sealed bonds with the water reslstance of wax seals and the strength of ethyl cellulose. A form of waxed paper has been dereloped with this laoquer. The ingolubility of the wax constituent makes it necessary to coat Rhodes and Vendorf's filn as a hot melt. The second patent, awarded to N. B. T1llotson (27), covered an ethyloellulose, resin hot melt for use on papers and plastio sheeting.

The pertinent ilterature in 1945 was devoted, almost entirely, to discussing the heat sealing of solid plastio objects. Jonos (28), Thomas (29), and Metzler (30) wrote related artioles on the subjeot of welding plastlo bodies together, the reaction to solvent sealing, heat sealing, and combinations of the two were discussed. The conclusions concerning ethylcellulose showed it to be the cellulose deriva- 
t1re plastio most adapted to heat sealing.

The established theories and methods for the use or ethylcellulose heat sealing lacquers were disoussed in three artioles published in 1946. Lamination by use of thermoplastio films and heated rolls was outlined and analysed by Smith (31) and Lelnbach (32). Both the nethod of applying the adheaive as a liquid and the use of a solld flim of adhesive were outlined and explalned. A. Jones (33) compared ethyl oellulose heat sealing flims to those of other cellulose esters. HIs conclusions recommend the use of ethylcellulose for most heat sealing operations. 
THEORI 
Heat sealing, for the purpose of this disoussion, w11l be defined as that process in which a dry thermoplastio substanoe is bonded to any meterlal by means of heat. This prooess consists of three operations. In proper order these operations are melting, or extreme sortening in the flim at the proper temperature, establishing close contaot between the surfaces to be bonded, and the setting of the melt to form the bond. All these operations take place more or less instantaneously in that it is diffcult to distinguish one from the other. The melting or softening of the film is brought about by contact with som outside source of hoat. Varled sources are in use, inoluding electrically heated irons, rolls, metal tapes, presses, and steam heated rolls. Recently dielectric heating has been applied in certain oases. The ectual temperature to which a film is subjeoted is a function of the temperature of the heat source, time of exposure to the heat source, and the overall heat transfer coefficlent from the source to the fllm. The temperature at whioh a f1la melts or beoomes plastic is a function of its composition and dffers for each lacquer. Presaure is applied to the softened fllm to establish contaot between the materials to be bonded. In oases where the sealing film is only softened by the application of heat, more pressure is required to insure a good seal. Heat sealing operations are generally contlnuous, and both the 
exposure to heat and application of pressure are only momentary for each seal. Sinoe the papers and folls are thin and retaln very little heat the softened films resolidify quiokly. l'o deorease the setting times, some operations include chliling seals immediately following the applioation of heat. In many instanoes ohflling has a hardening effoct which tends to strengthen the bond.

Heat sealing agents are defined as thermoplastio materlals which can be formed into flims or can be ccated upon paper or other films and are reasonably normal, nonstioky sollds at ordinary temperatures, but which melt or becane very stloky at temperatures ranging from 150 to 300 degrees 1. (34).

As in the case of paraffin wax, some of these agents are pure substances. The large majority, however, are produoed from the comblnation of two or more pure constltuents to form a laoquer or hot melt coating. The formulation of a coating to be used in heat sealing consists of adusting three properties of the laoquer system in question. The first property to be adjusted is adhesion. The laoquer must be made to stlok to the materials to be bonded. Seoondly, the lacquer'a melting or softening point must be adjusted to the desired temperature. The final adjustment oomes in making the film as flexible as posalble without softening it to the point of 
tackiness. In the pure state, ethyloellulose films adhere pooriy to most substances. To inprove adhesion the addition of certain modifying agents is necessary. The modifying agents usually added for the purpose of inereasing adhesion are resins, either natural or synthetio. Resin adaition, as will be discussed later, also affects other properties, Resins added to ethyloeliulose films must be of a type that w1ll form solld solutions with the ethyloellulose. By adding the proper resin, ethylcellulose flims can be made to adhere to almost any surface. Bthyloellulose, in the pure state has a melting temperature of from 170 to 220 degrees $C$. Its exact melting point is a function of its ethoxy content. The ethoxy content Is a measure of the number of $\mathrm{C}_{2} \mathrm{H}_{5}$ units joined to each oellulose ring. Figure 1 is a curve correlating melting temperature with ethoxy content of pure ethyloellulose. To ohange the temperature of pure ethyloellulose, It is necessary to add terials to afferent melting points. In adition to rosins, non drying liquids oalled "plastiolzers" are added for the purpose of melting polnt control. For general heat sealing the melting point of pure ethylcellulose is too high. It is the general rule, therefore, that the modifying resin and plastioizer have melting polnts below that of ethylcellulose. The resins most comon to coating applications melt at temperatures of from 0 degrees $\mathrm{C}$. to 150 degrees $\mathrm{C}$. 


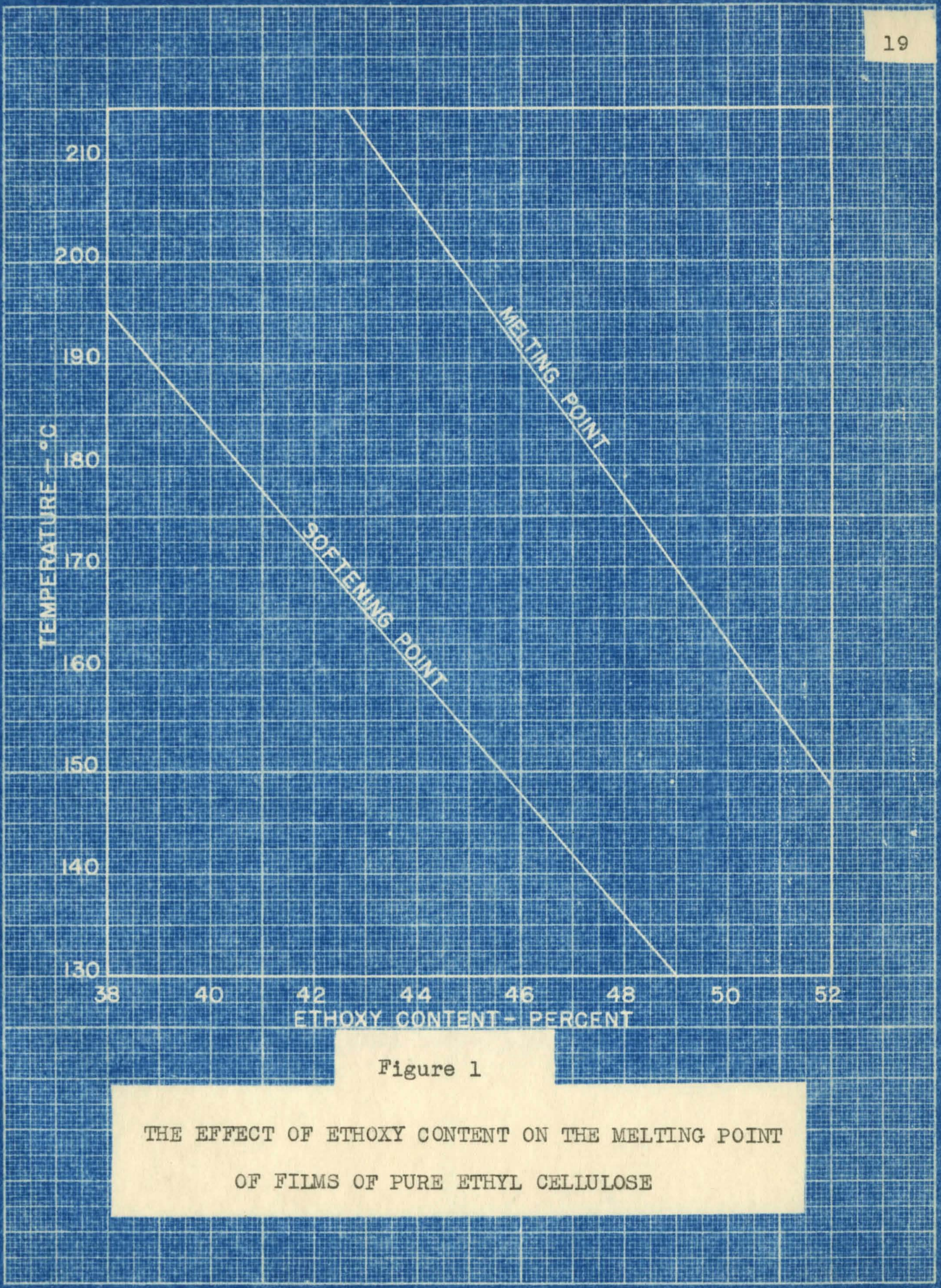


There are resins designed for extremes in temperature, but they are not widely used as laoquer constituents. Plastiolzers which are liquids at normal temperatures melt at temperatures below $0^{\circ}$. The addition of elther or both of these materiala, if a solid solution with thylcellulose is rormed, results in a temperature below that of ethylcellulose. Figure 2 is the melting point alagram for ethylcellulose of 45\% othoxy oontent, in solld solution with Amberol F-7.

The term compatibility is used to designate the composition range over which two or more constituents go together to form homogenous solid solution. The addition to a system of enough of any one component to exceed the limit of compatibility gives a film having a non-homogenous appearanoe. Such an appearanoe is called blushing. By proper addition of resins and plastlolzers compatible with ehtylcellulose and having known thermal properties, a flim can be made having the desired melting point.

Films of ethyl oellulose are quite flexible. The addition, howerer, of solld resins tends to destroy that flexibility and fom films that are too brittle for use. If such a resin is to be used, the f1lm must be plastiolzed to retain flexibility. The usefulness of plastiolzers is limlted by their softening effect on ethyl cellulose films. Films only slightly softer than pure ethyl oellulose begin to show 


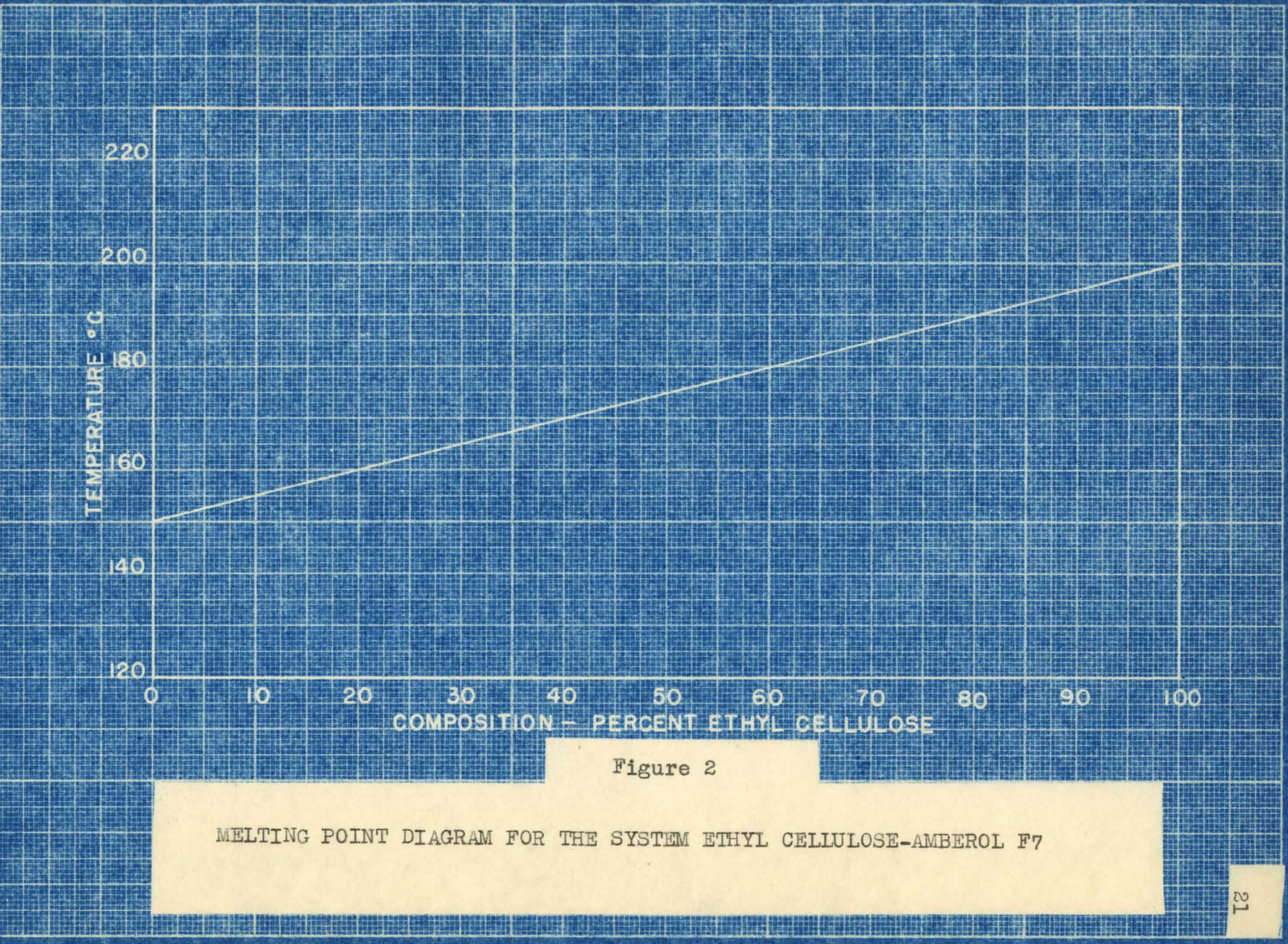


signs of blocking under normal storage conditions of heat and pressure.

The adjustment of adhesion, melting temperature, plexibillty, and blocking characteristics is a matter of experimental formulation. In praotioe, known mixtures of ethyl cellulose, resin, and plastlelzer are dissolved in some sultable organic solvent. The 11 quids thus formed are coated on some carrier medium and evaluation tests made. The general requirement of resins and plastiolzers is that they increase adhesion, lower the melting polnt from that of ethyleellulose, preserve the film flexibility, and have minimum softening erfect.

Whyl cellulose laoquer systems, as has been previously explained, are three component aystems. It is, therefore, convenient to express the results of property ovaluations on trlangular coordinate graphs (35). Such a graph is 11lustrated in Figure 3 . It consists of an equilateral triangle divided by qually spaced lines parallel to the three bases. Waoh apex of the triangle represents $100 \%$ of the material there shown. Hach base ifne represents of of the terlal shown at the opposite apex. The altitude drawn from any one apex is divided into 100 equidistant unlts representing per cents from 1 to 100 .

The perpendioular distanoes from any polnt on the 


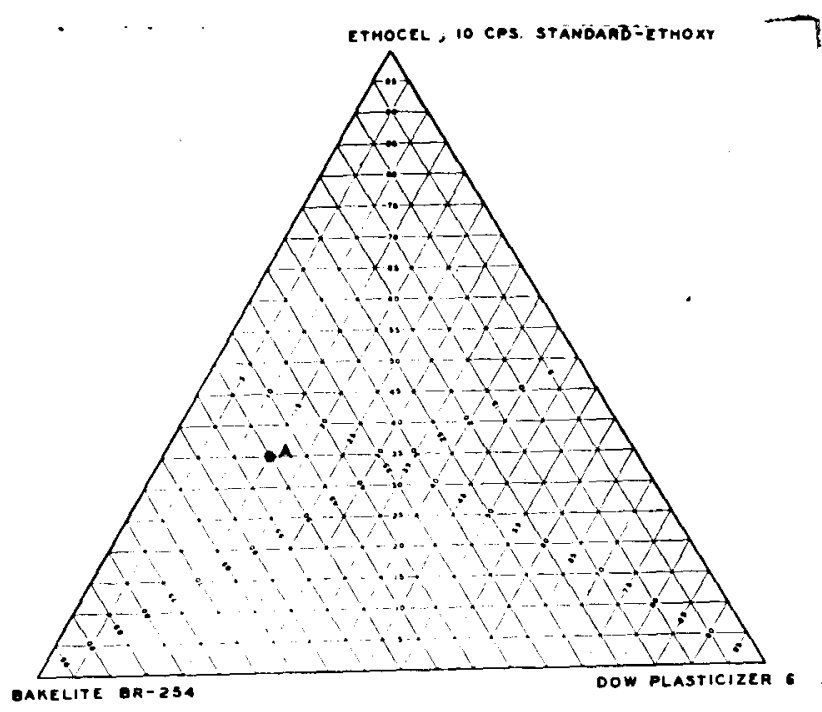

Pigure

PLCTTING A LACQUER SOMPOSITION ON A THATZ COMPONENT DIAGRAM
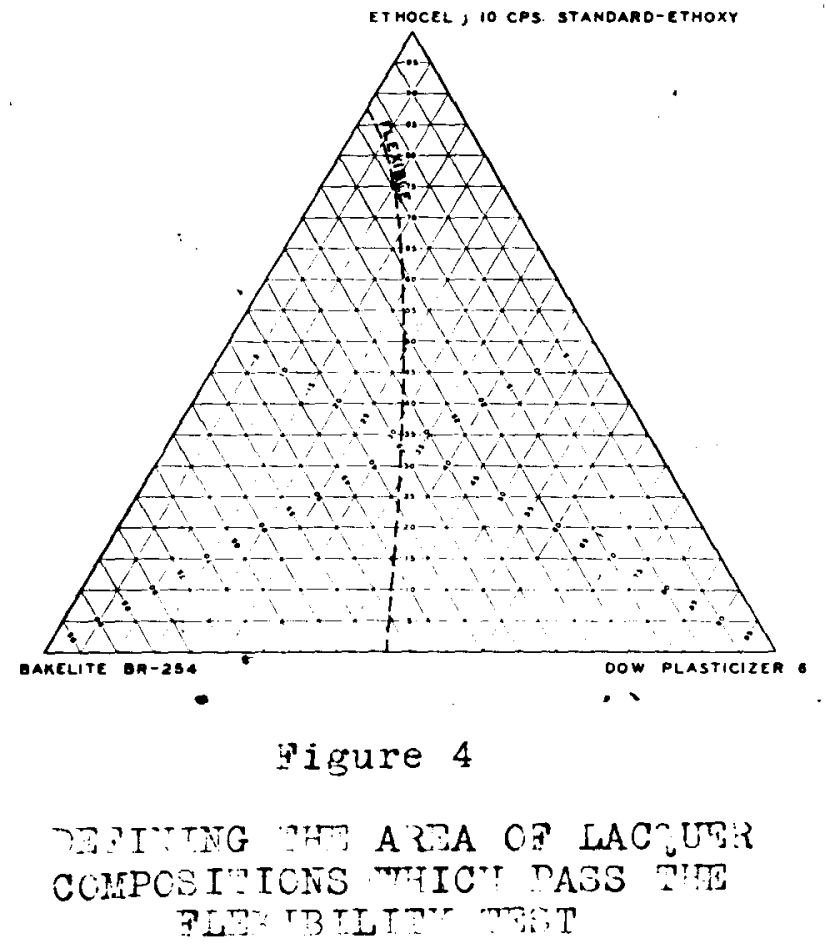
surface of the diagram to the three sides is equal to the altitude of the triangle. Therefore, any point within the triangle represents 100 parts of total sollds. For examplo, point A represents a laoquer containing 50\% Bake 11 te BR-254, 35\% Ethyl oellulose, and 15\% Dow Plastiolzer 6, or a total of 100\%. It is evident, therefore, thet all possible mixtures of the three components are represented on one trilinear diagram.

Laequers are formulated to represent points evenly distributed over their trlangular ooordinate diagram (36). The laoquers thus formulated are tested for the properties desoribed previously. By conneoting with a continuous line all compositions having the same property, a ourve is obtalned. That curve separates areas passing the tests from those that do not. Figure 5 is a curve of the type desoribed above. F1gures 5 and 6 are simliar diagrams showing cold oheok resistance and print resistance. Customarily, the area containing the descriptive word has that property designated by the word.

A sys tem, to satisfy the requirements spoolfled for this work, must have a triengular chart whose Plexibility, non-blooking, and ahesive areas orerlap each other. 


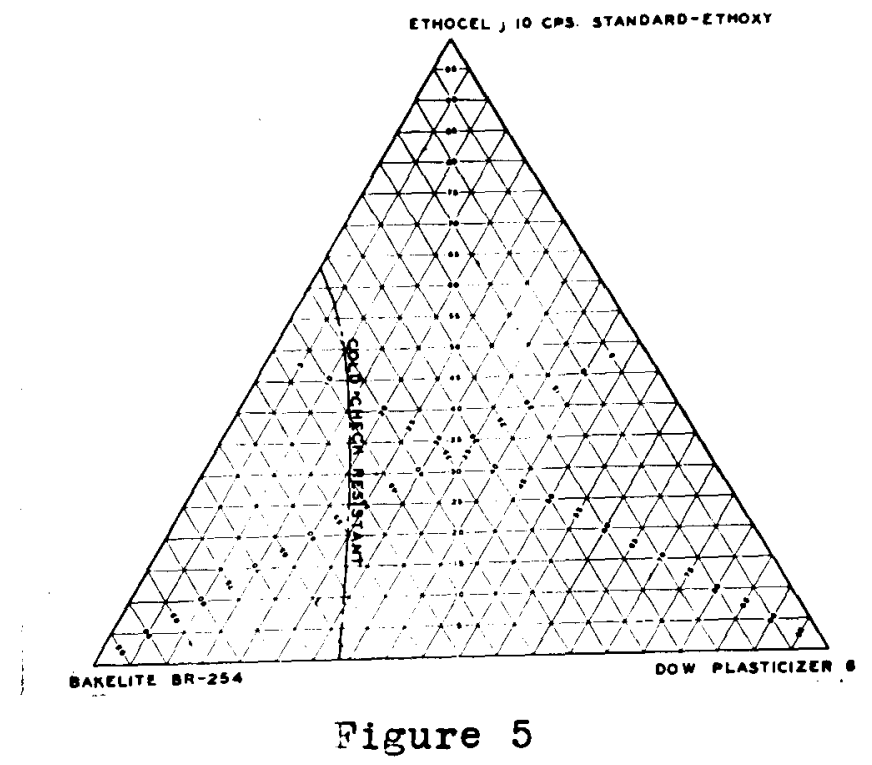

DEFINING THE AREA OF LACQUER COMPCSITIONS WHICH HAVE COLD CITCK RESTSTANCE

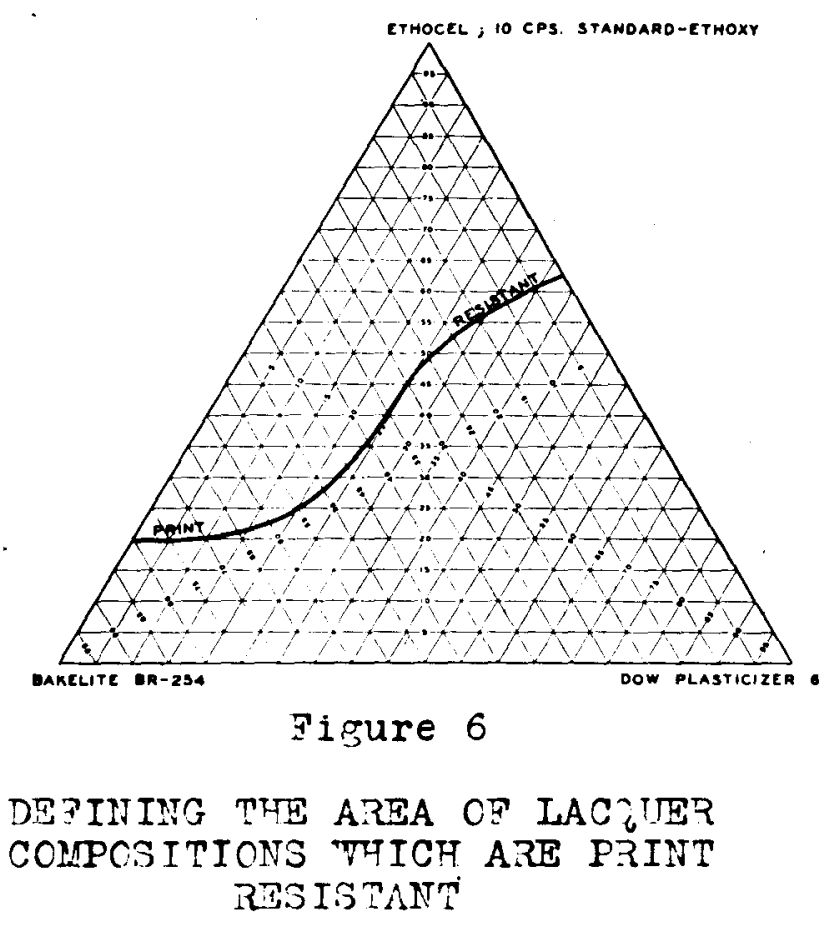


EXPERTMETTAI 


\section{PROCFDURW}

The experimental proeedure followed oonsisted of evaluating the heat sealing propertles of different laoquer systems. The evaluation was made up of three operations: rormulation, applioation, and testing.

Trlangular oomposition dlagrams were prepared for each system to be tested. On these diagrams eveniy distributed polnts were chosen orer the entire area. The polnts ohosen for each system are plotted on Figure 11. Baoh of the chosen polnts represented a samplo lacquer formulation. Ten grams was ohosen as the total sollds wolght for each sample. Thi. wight made it posmible to formulate, without further computation, a laequer from compositions shown on the system's triangular chart. Samples haring the desired composition were alssolved in a 70-30\% mixture of toluene with othanol. Inough solvent was added to lower the laoquer viscosity to a polnt where it flowed easily under the blade of a .006 Inoh dootor knife. Normally the amount of solvent was 7.3 oo solvent per gm. ethyl cellulose. Formulae containing carnauba wax required heat to dissolve the sollds completely. An eleotrio hot plate was used to supply the necessary heat. Aluminum foll was specifled as the modiun on whloh test flims were to be east. The foll used on these testa was Reynolds' 2SH 2-0, .004 inohes thlok. Films were cast 
by hand on the pollshed face of the foll by doctor blades (37) or the Dow Ethooel Caster. Figure 7 shows f12ms belng cast with the Ithooel Caster. Both bledes and caster were set to cast films to a wet thiokness of .006 inches, Dry film thloknesses, determined on a Randall-Stickney thlokness gauge, alffered for each formulation. Films were air drled for 24 hours before testing.

The followlng tests were set up for the evaluation of film propertiea:

Adhosion

Aluminum foll, ooated with the film to be tested was cut into strips 2 by 4 inches. Strips having the sane dimensions were prepared from the material to which a seal was to be made. This material was ugually foll, glassine paper, collophane, or a similar strip of coated foll. The two materlals were then placed face to face, separated by the laoquer $11 \mathrm{~m}$ coated on the aluminum foll atrip. The two materials were sealed by pressing with an eleotrio hand iron. The face of the 1 ron was regulated to 150 degrees $\mathrm{C}$. by means of an iron-constantan themooouple. One pass of the Iron was used. Pressure on the sample was that of the 1 ron only and was approximately .3 psi. Sealed samples were quiokly cooled to roan temperature by boing held on a water cooled steel plate. 


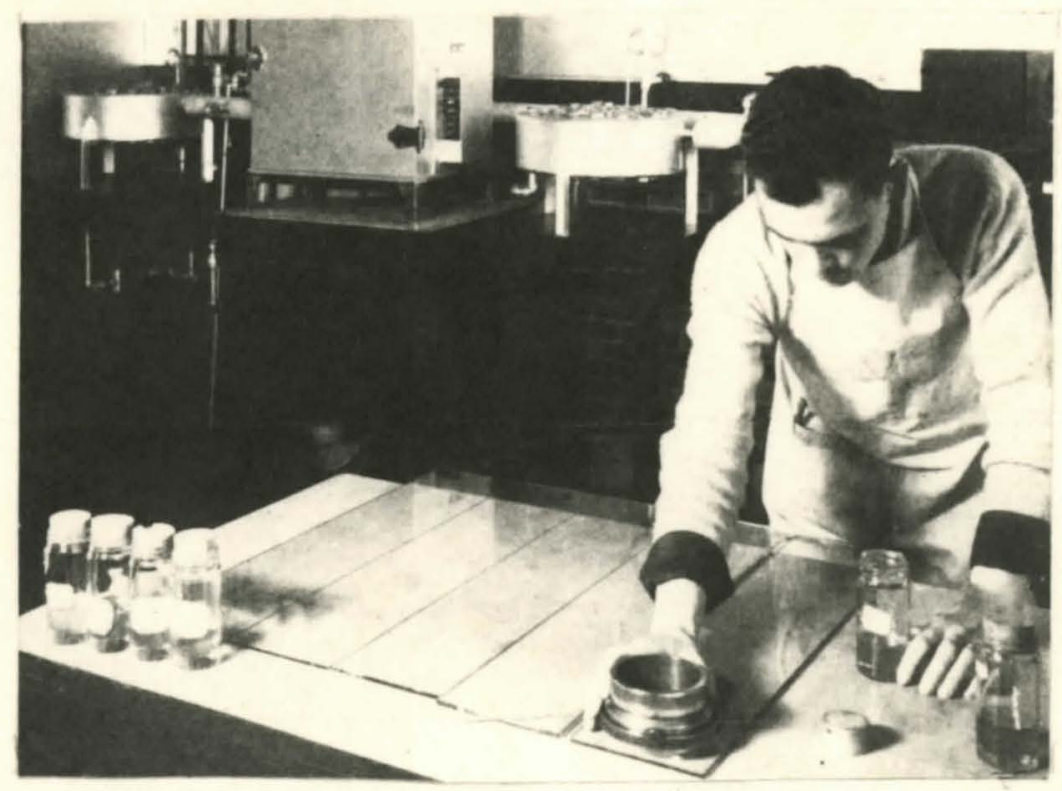

Bigure 7

CASTING FILMS OF ETHYL CELLULOSE

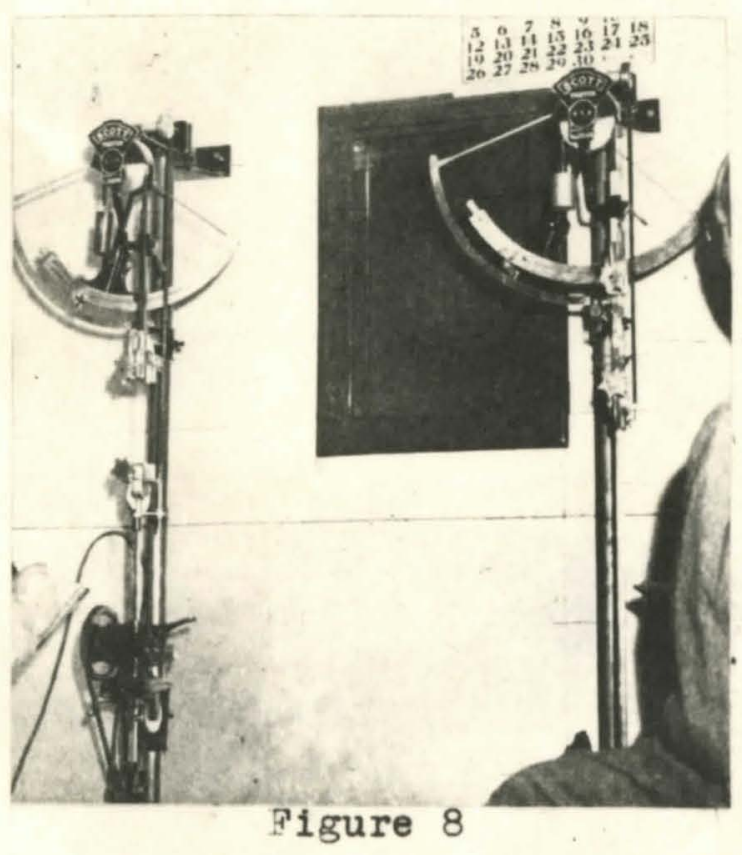

TESTING ETHYL CELLULOSE

FILMS ON THE SCOTT FILM TESTER

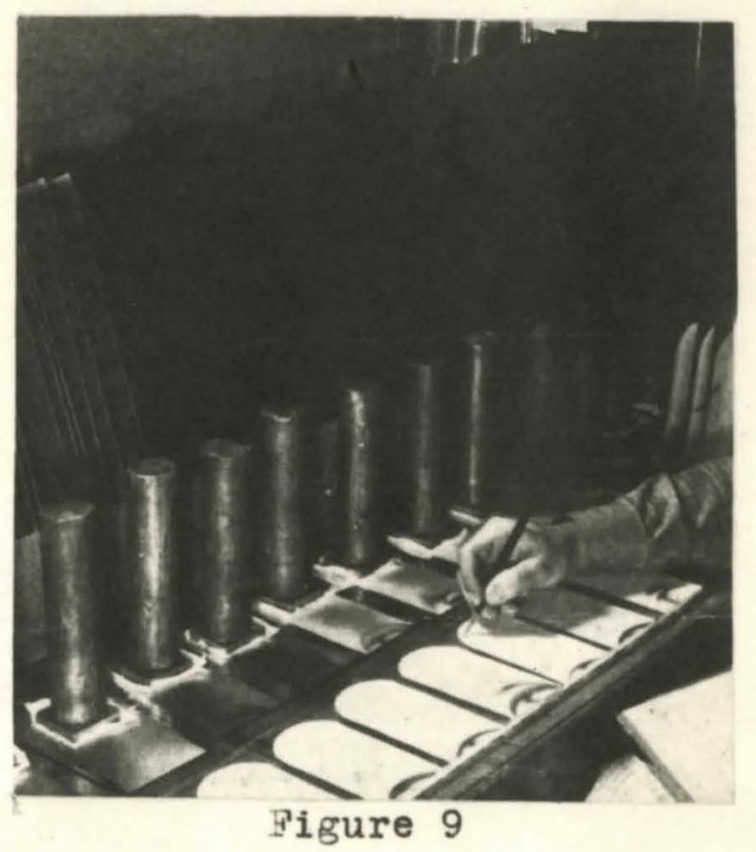

TESTING ETHYL CELIULOSE FILMS BY THE PENCIL TEST 
Samples, after having been sealed, were tested fos adhesion. Two methods were used to make the adheaion teat. The rirst consisted of pulling the sealed strips apart by hand. Bonds that held until the foll or paper tore were rated adhesive. Although the hand stripping method has the advantage of speed, it is not accurate. Bonds not strang enough to be tearling bonds oan not be further rated by hand stripping.

Slower but more cocurate adhesion tests were made on the Soott Filn Tester. This method was applied to samples that sealed with strengths less than tearing bonds. The Soott Film Tester was originalis designed to test tensile atrengths of films, ribers, and packaging materlals. It consiste of a low speed, varlable drive motor, a balance dial, and clamps for holding thin flims. The ends of the film to be tested are placed in the two olamps. Tension is slowly applied to the film by the motor. A continuous measurement of this slowly increasing tension is regiatered on the soale.

Seal strengths are measured on the Scott Tester by plaolng the ends of the sealed materials into the olamps. Tension is then applied at right angles to the seal. Since the scale is arranged to read maximum strengths, it will show the highest strength developed by the seal berore 
fallure. Figure 8 shows Soott Film Testers in operation. Blooklng

The problem required the rilm to be non-blooking at $50^{\circ} \mathrm{C}$. under $1 \mathrm{ps}$. Teat samples for the block test, as in the adhesion test, were aluminum foll strips coated with the flim to be tested. The sample strips were folded, flim inside, thus making a $11 \mathrm{~m}-\mathrm{t}_{\mathrm{-}} \mathrm{fl}$ in contact. Samples folded in that way were, then, placed on the center tray of a convection oven set at $50^{\circ} \mathrm{C}$. under a pressure of one ps1. After 24 hours at $50^{\circ} \mathrm{C}$. the semples were removed from the oven and oooled to room temperature. The folded foll was then hand stripped in the same manner as were the samples tested for adhesion. Samples showing no tendenoy whatsoever to stlak or become tacky were rated non-blooklng.

\section{Iexib114tr}

The flexibility of sample films was rated by hand creasing. Aluminum foll strips coated with the film to be tested were creased, film slde out, by hand. The oreasing was repeated with a rolling motion for 25 complete creasings. M10 rosoop 10 examination revealed any film oracking caused by this test. F1Ims showing no oracks after 25 oreasings were rated as flexible.

\section{Compatib111ty}

A slight haze, oalled blushing, is a good indioation 
of basic incompatibility. Several ot her factors, however, can temporarily cause a film to blush. Improper solvent, abrupt cooling, and Insurfiolent mixing are the most prevalent of those ractors. Samples showing any tendency to blush when drying on aluminum foll were remelted. This was done by passing the coated foll over a hot plate at $200^{\circ} \mathrm{C}$. Films blushing after this treatment were rated incompatible. Hardnegs

The standard Pencil Test (38) was used to rate the hardness of sample films. A set of sharpened drawing penolls was used in the test. Sample lacquers were costed on glase panels and alr dried for 24 hours. Testing the flims consisted of marking the films with penoils of inoreasing hardness. Hand pressure must be kept constant. The hardness rating of any film is reported as the softest penoll that will make a distinot mark in the rilm. Figure 9 shows films belng subjeated to the penoil test. It was decided, however, that the blooking test and hardness tests for purposes of thls work duplicated each other. The hardness test was discontinued as the blocking was the more pertinent property.

Asing

The retention of properties in rilms pessing all other tests was checked. Fo1l coated with the f1Im to be tested was out into strips. Various forms of the coated fo12, 
both sealed and unsealed, were made up and stored at room temperature. Adhesion, blookins, and flexibility tests were run on these samples at intervals of 7 days. Changes in the original properties of the sample were noted.

\section{Cold Storage}

Samples passing adhesion, blooking, and flexibility testa were tested for loss of properties at cold storage temperatures (39). Samples prepared in the same way as were those for aging tests were plaoed in direot contact with dry 10e. After 24 hours contact with dry 100, they were transferred to the ereezing compartment of an $8 \mathrm{ou}$. ft. eleotrio refrlgerator. Following 72 hours in the freezlng oompartment, the aamples were tested for adhesion, blooking, and flexibility. Changes from the original properties of the sample tested were reoorded.

\section{Machine fiesta}

Samples consldered to be autable for use as heat sealing agents were tested by industrial applioation. Two operations in the Brown and W1111amson Tobacoo Company plant in Loutaville, Kentuaky, require a beat seal. The first conalsts of sealling the longltudinal paper seam on a olgarette. In the case of one partioular brand a cork tipping is also sealed in this operation. A 11 quid glue is used to seal the cork to the clgarette paper. The overlapping cork 
to cork joint is the only portion of cork exposed to a sealing iron. The seoond operation consists of the manufacturing of a one plece clgarette package. This package, made of roil precoated w1th a heat seallng agent, is sealed entirely by heat sealing prooedures. Figure 10 is a somple of foll laminate used in this operation. Careful inspection w111 show the adhesire patterns coated on the edges of the laminate. Bthyl oellulose laoquers were tested on these machines by hand coating them on rolls of cork tipplng and paokaging foll. The film was thoroughly dried before rerolling the foll or tipplag. Clgarettes and packages were made with these coated materials. The lacquers were rated by comparing products sealed with them to those sealed by the regularis eraployed adhestves. The results from eaoh system were plotted on a trlangular dagram. Figures 11, 12, 13, and 14 11lustrate, for the system ethyl celluloseNevillac S-Aroohlor 1262, the method by whioh all the triangular diagrems were made. The dagrams were first plotted from the results of individual tests. These plots were made, as is 112ustrated in Figures 11,12 , and 13 , by separating the laoquers passing a given test from those failing to pass the same test. The individual plots were then comblned to form the overall d lagram. Such a combination is illustrated in the combining of Figures 11,12 , and 13 to form Figure 14. 


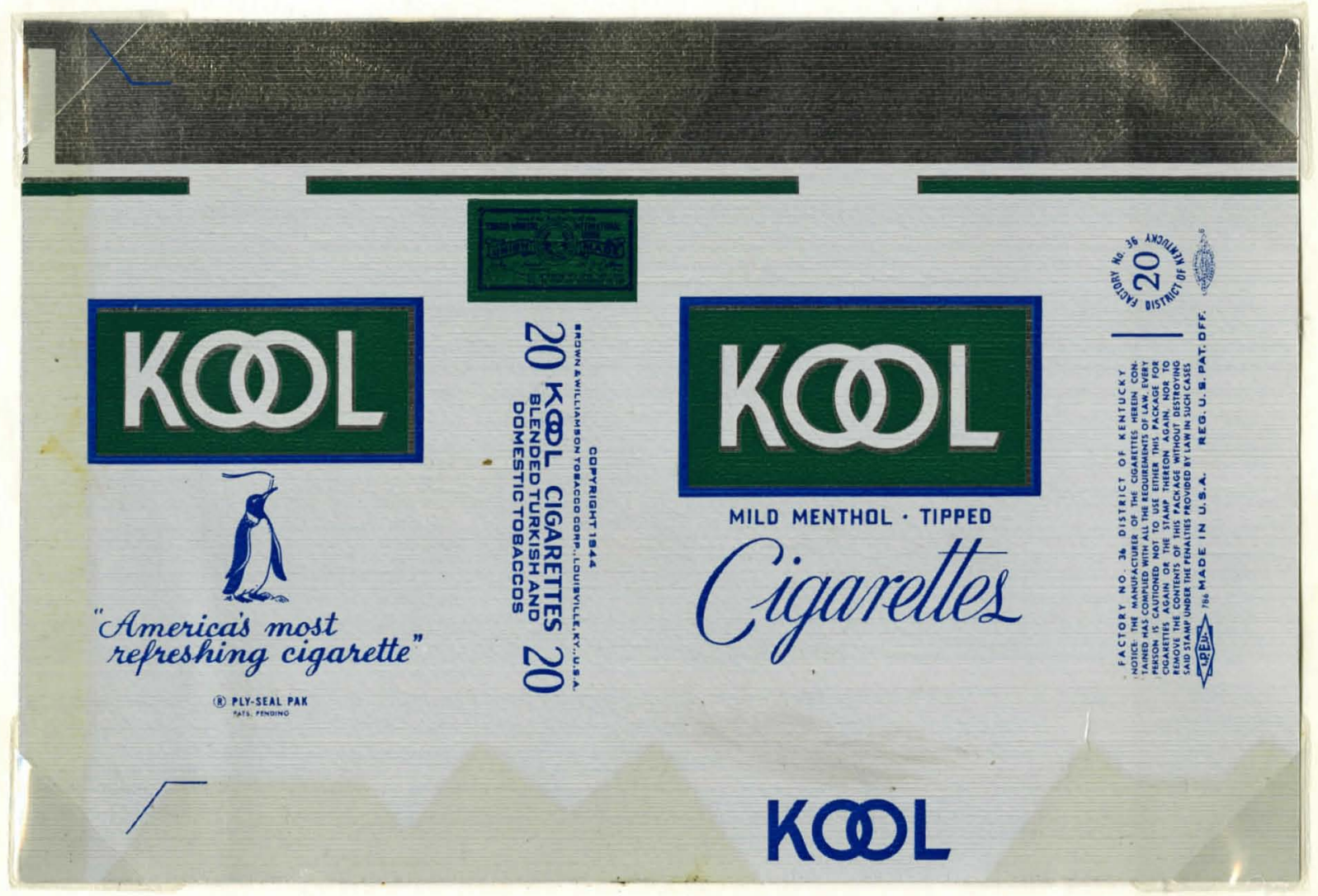

Figure 10

FOIL LAMINATE USED IN BROWN-WILLIAMSON

HEAT SEALING PACKAGER 


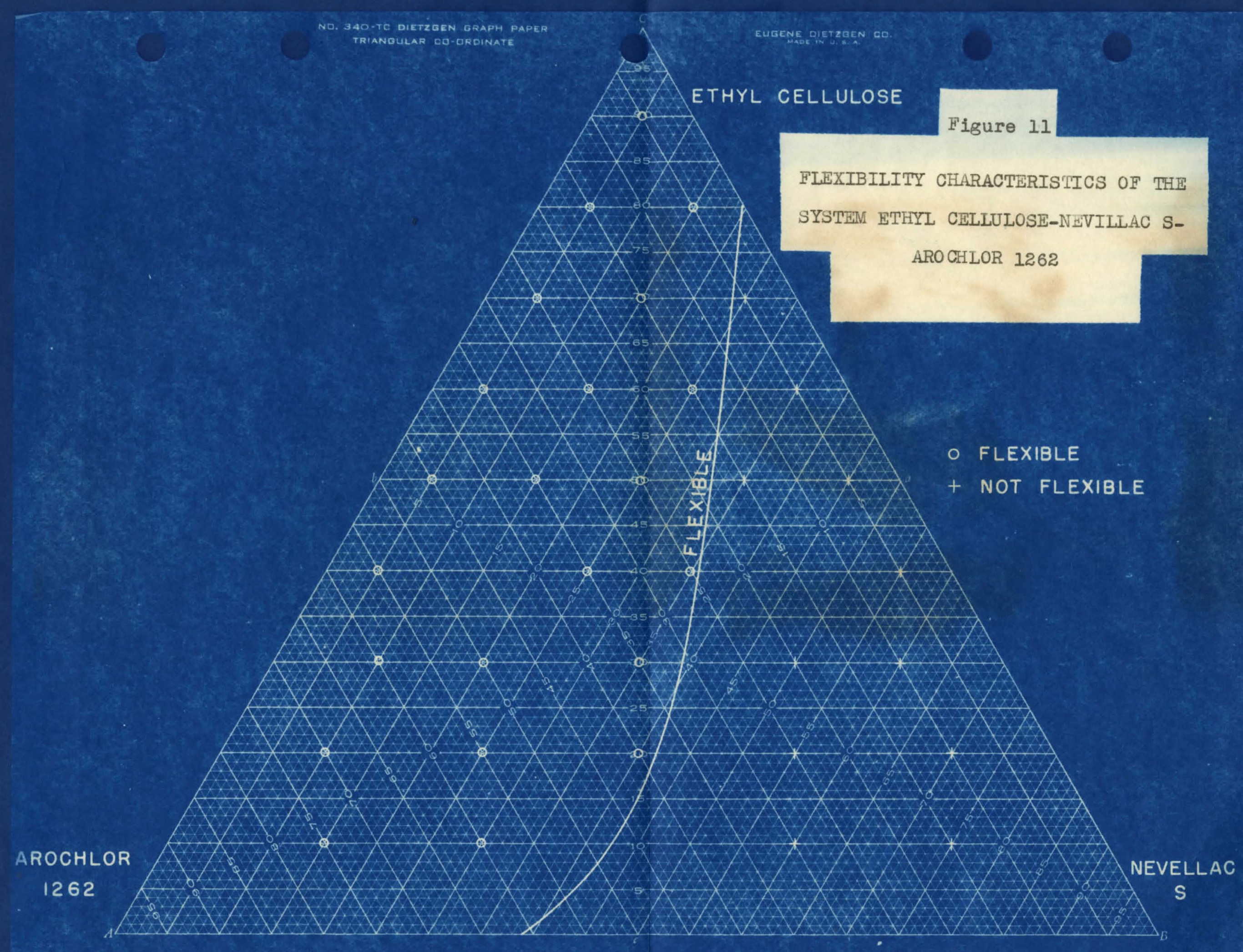




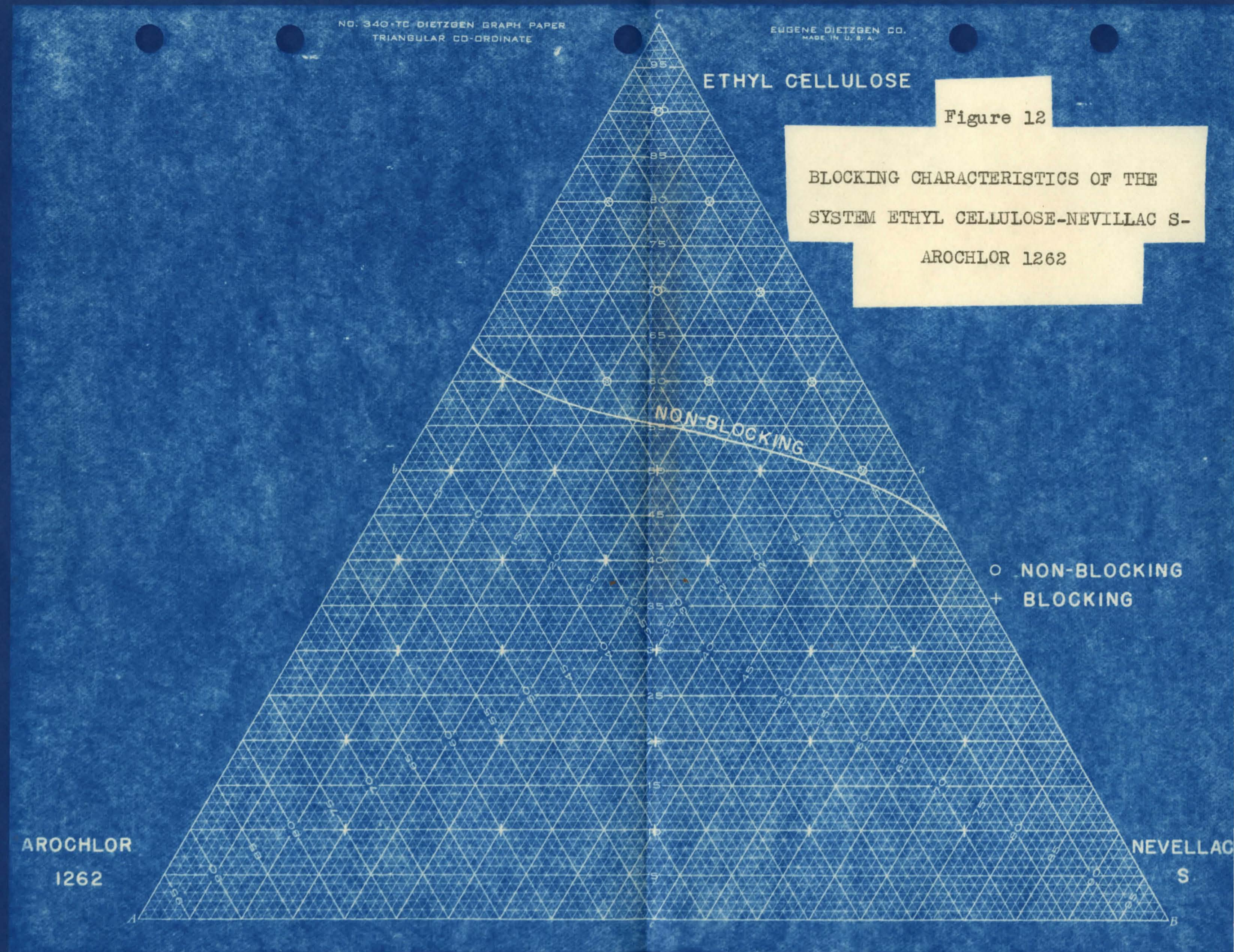




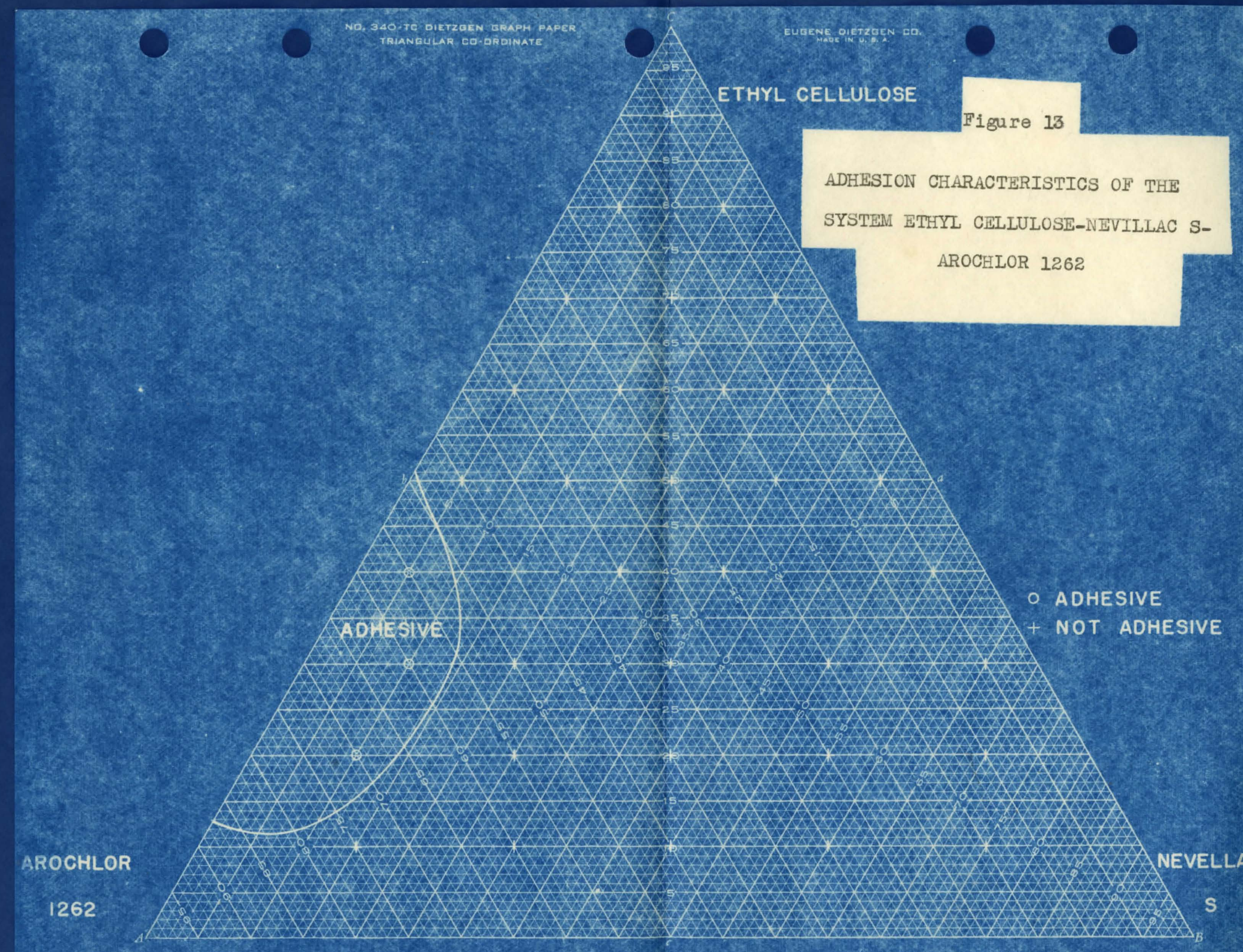




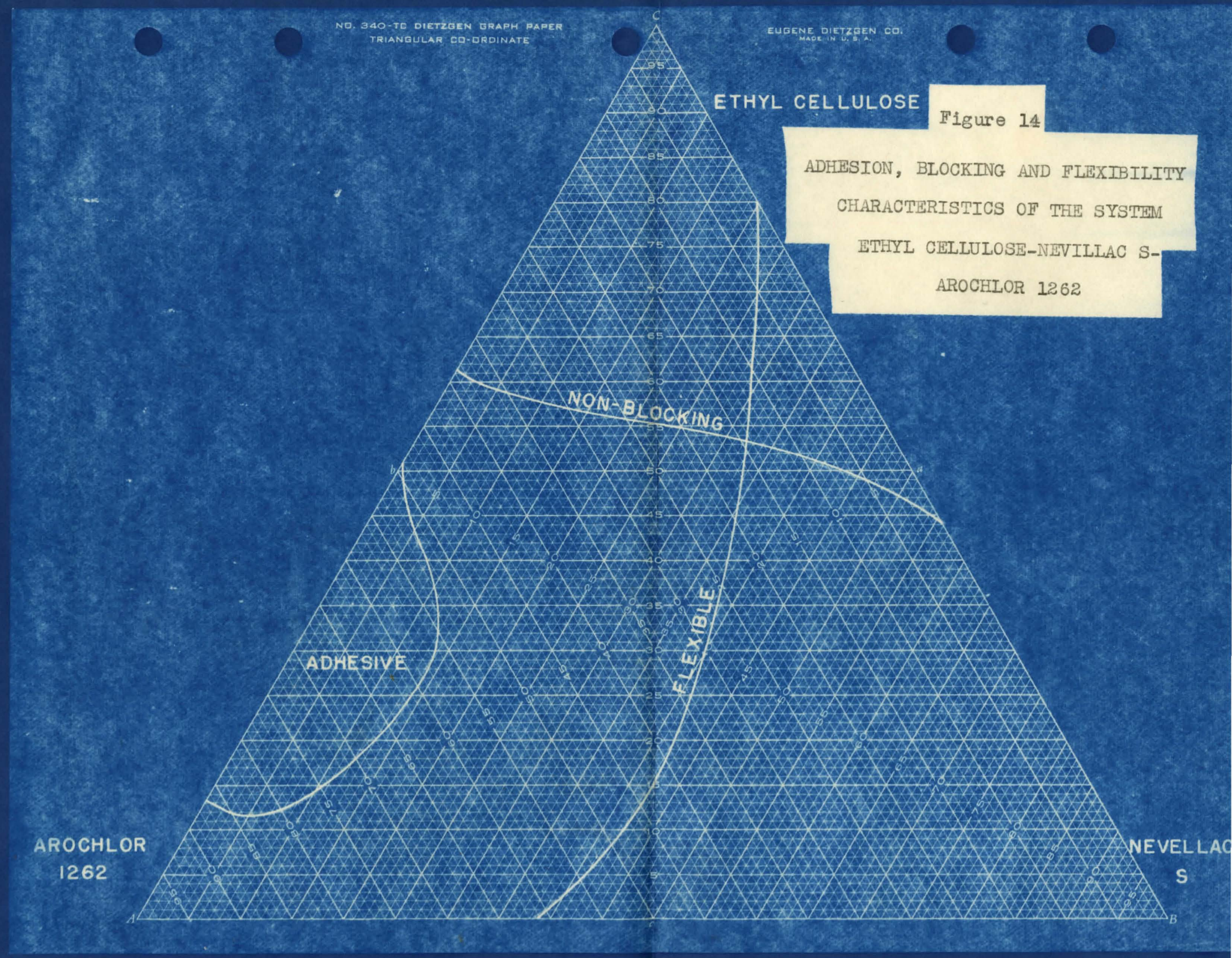




\section{RISULTS}

Results from adhesion, blocking, and flexibllity tests were rated as good, ralr, and poor. "Good" Indicates sat1sfactory passage of the test. "Fair" represents intermediate results while "poor" Indleates complete fallure of the test.

A large majority of the systems tested were not suitable for the formulation of a heat sealing laoquer. In generel the best adhesive properties ocourred in laoquers of high resin and low thyl oellulose composition. High ethyl cellulose compositions give the best blocking characteristios. Only three systems were found from which lacquers comblining adhesion and non-blook could be formulated. Table I Indicates the results obtalned by rating, for each system teated, the properties of the laoquer that best combined the properties adhesion, non-blook, and plexibility. Tables II, III, and IV list the properties of all two-component lacquers tested. Propertles of all three-component laoquers are graphloally shown in 1gures 14 through 21 .

The three systems best combining the se propertio s are ethyl cellulose-Arochlor 1262, ethyl cellulose-Dow resin 276-V2-trioresyl phosphate, and ethyl cellulose-Dow resin 276-V2-Dow plastiolzer No. 5. Carnauba wax was added, in small quantities, to each of these systems to improve blooking 


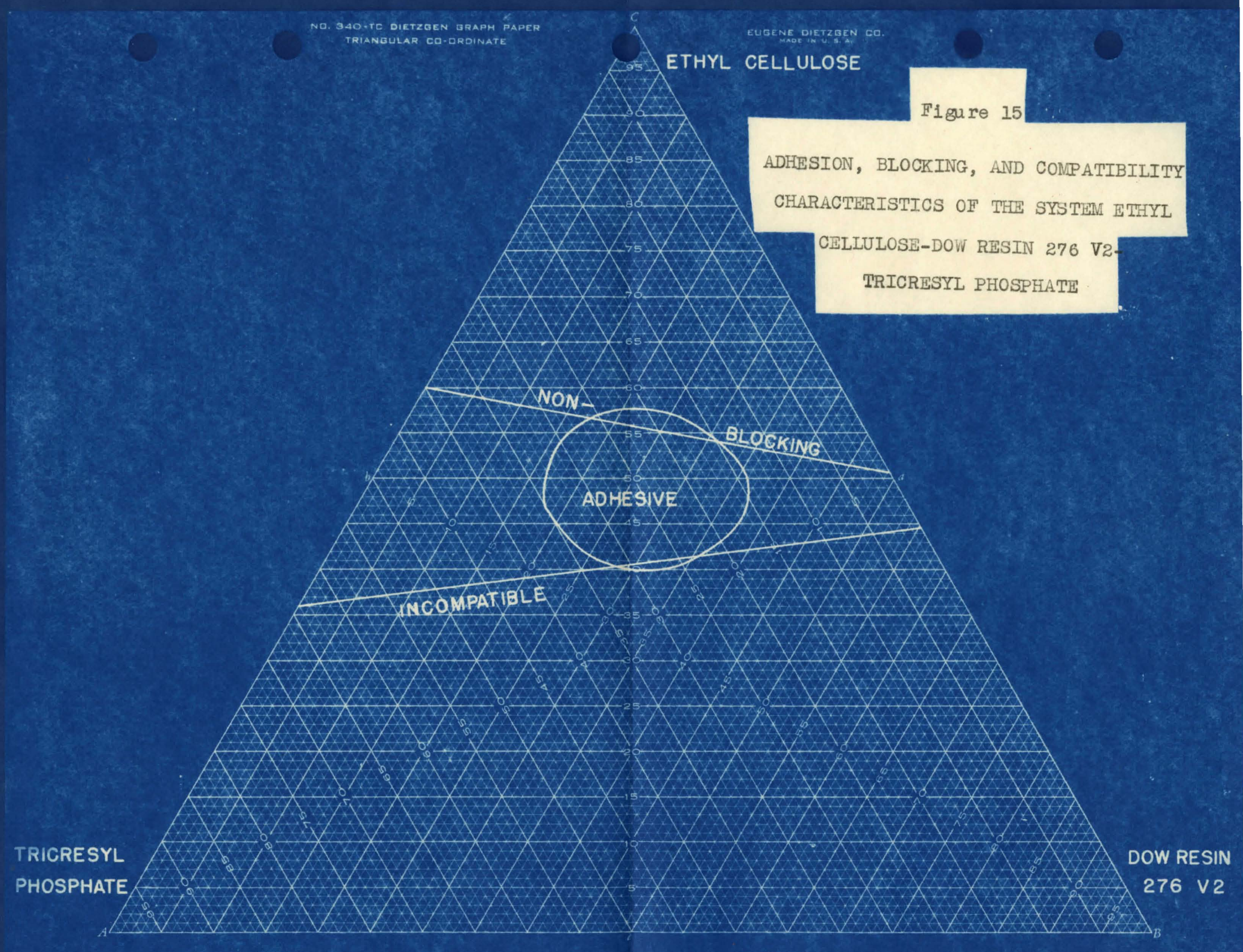




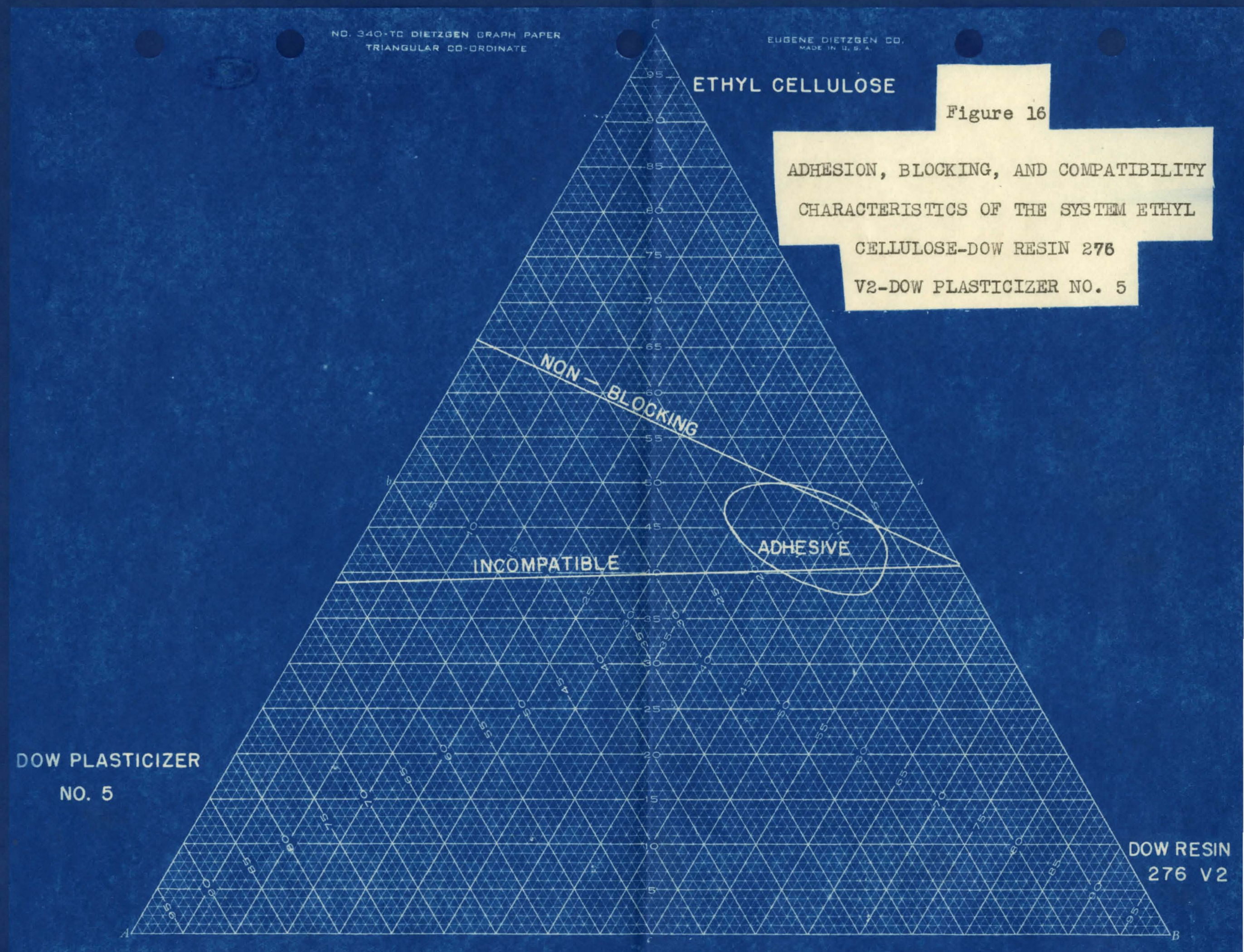




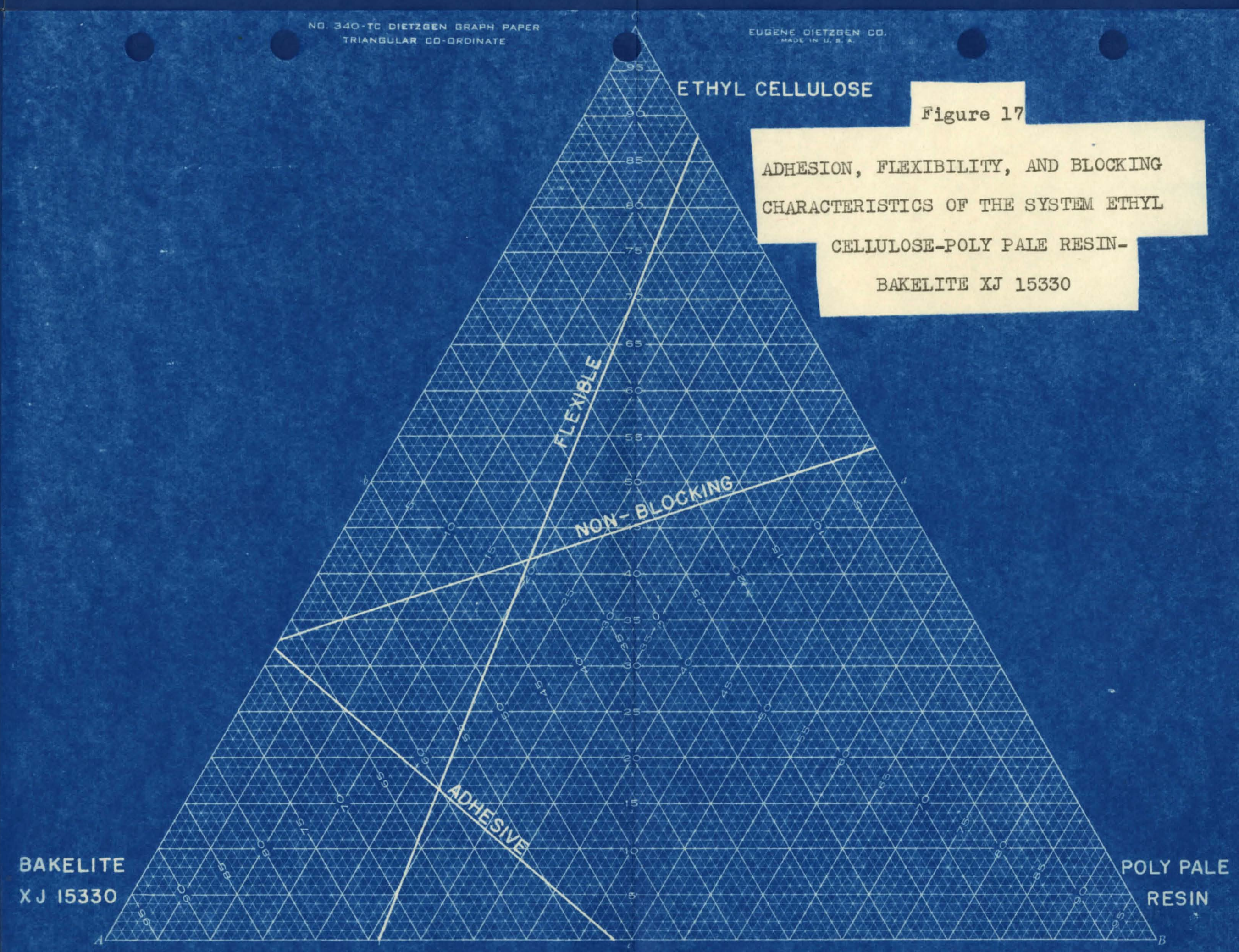




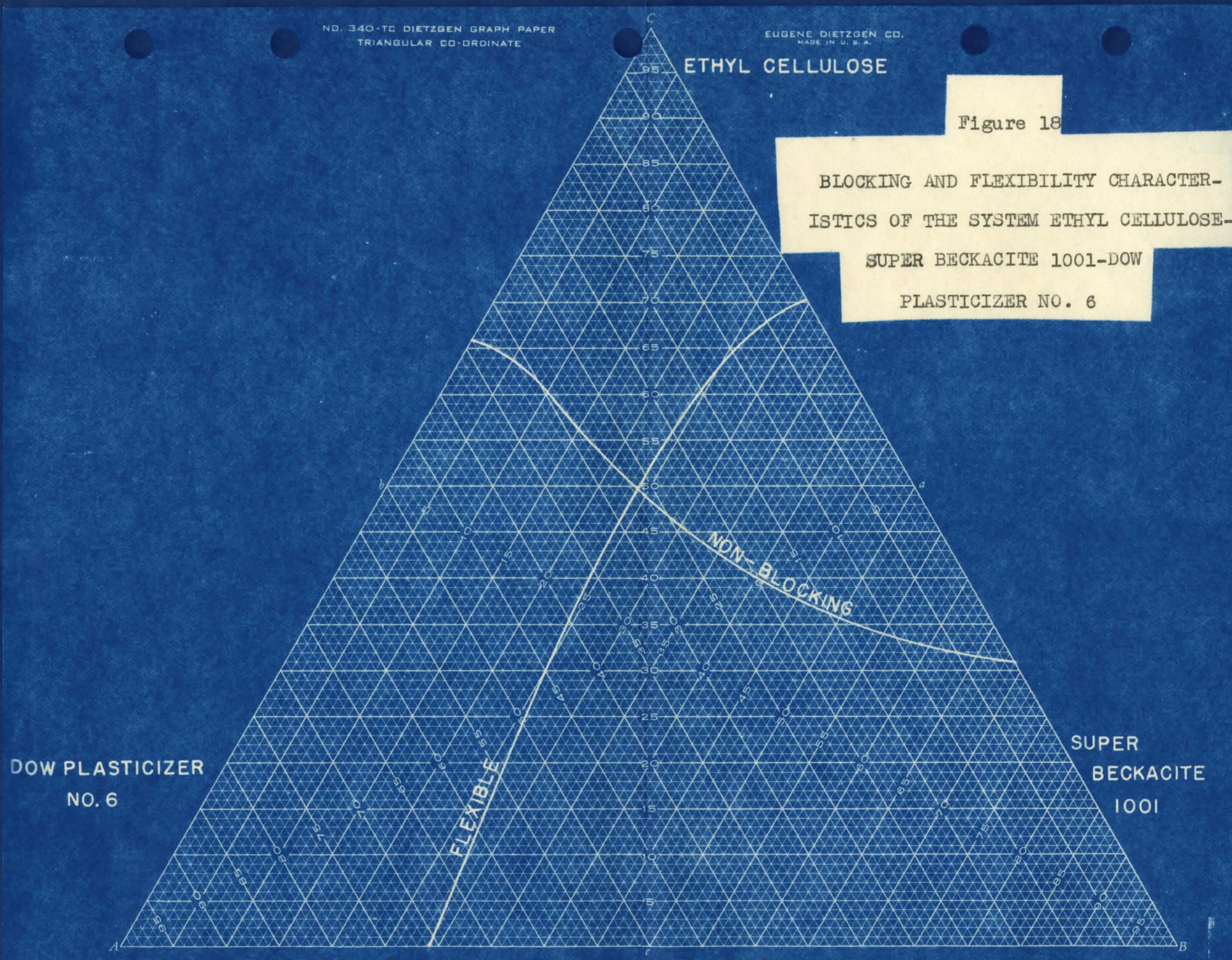




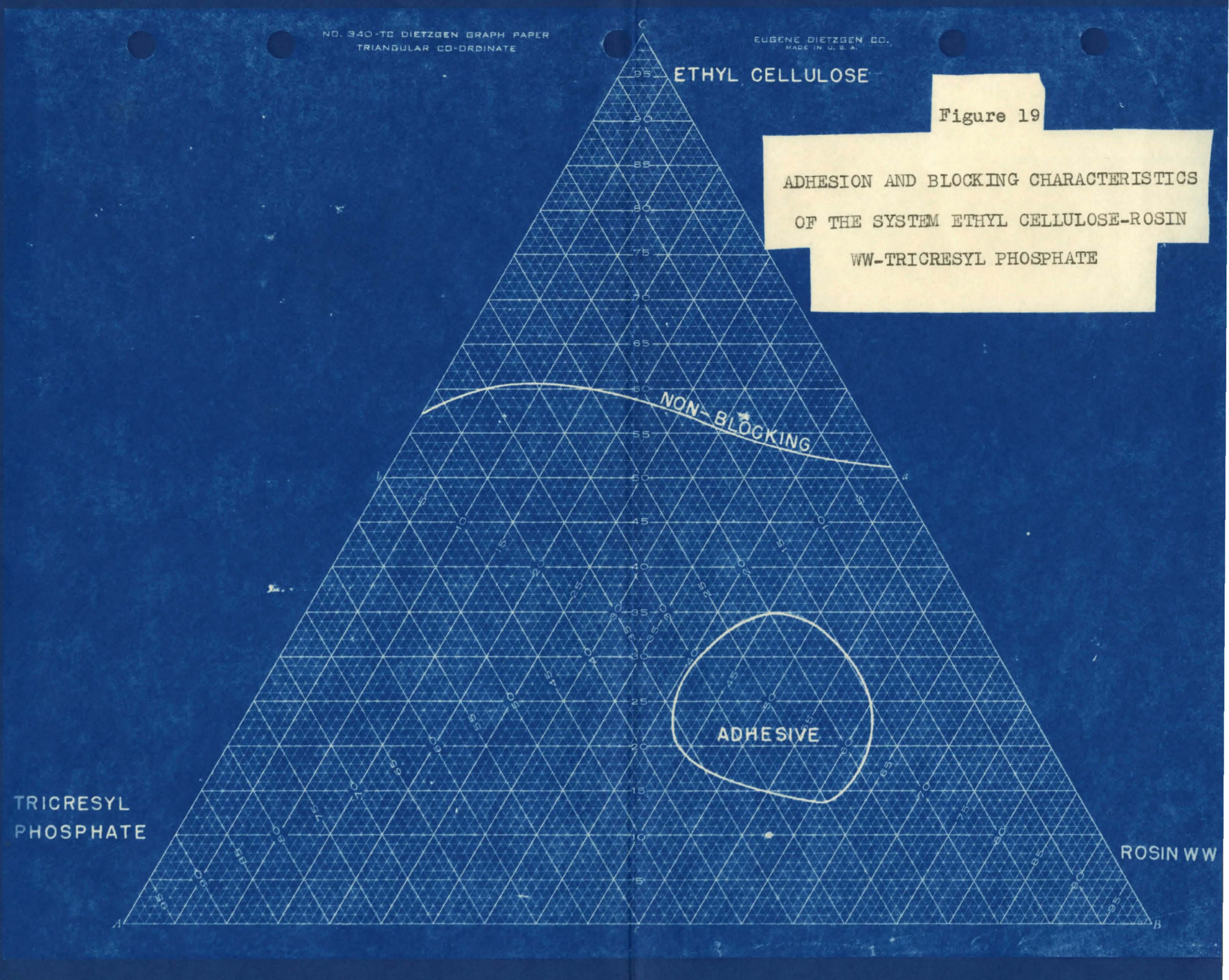




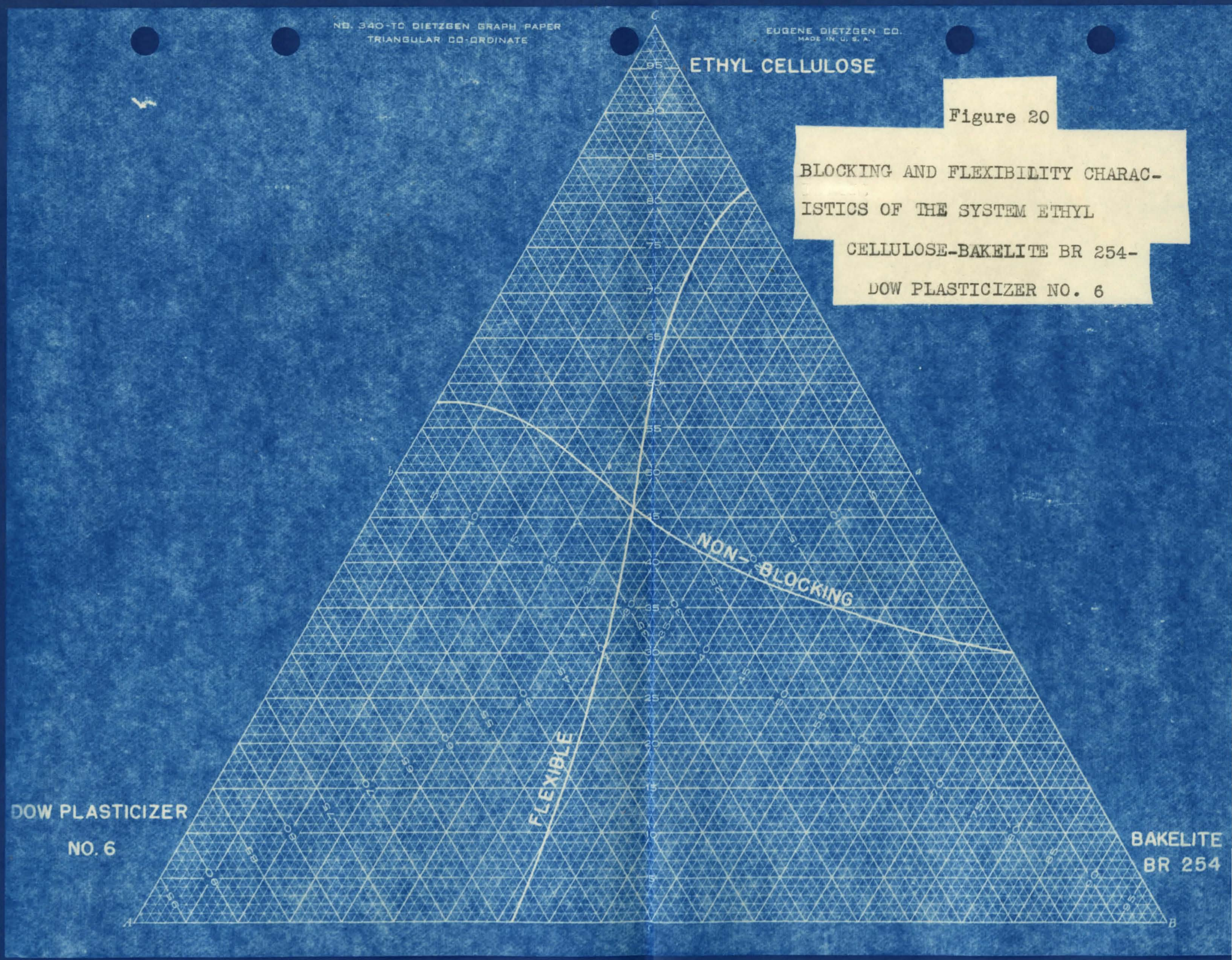




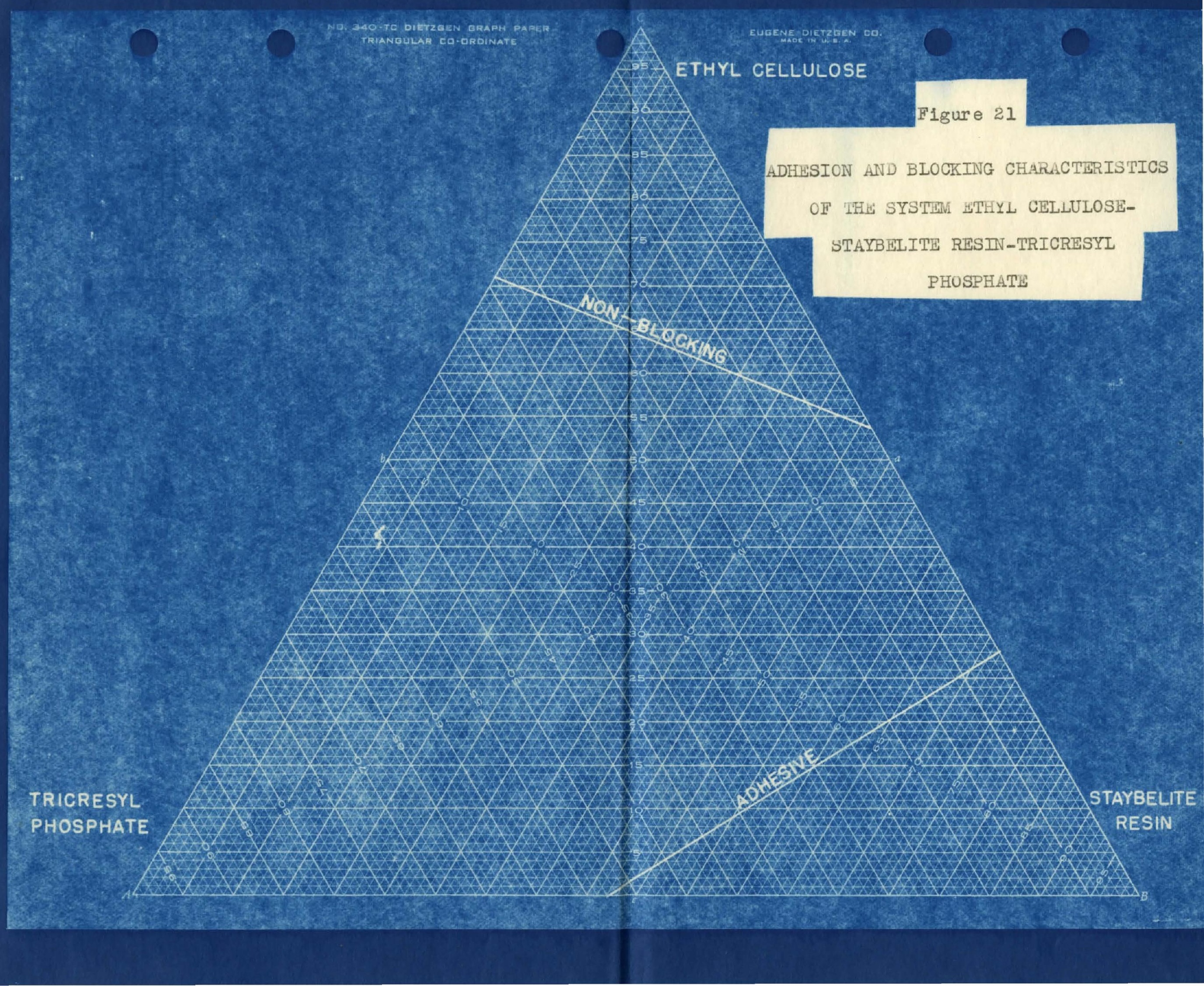


characterist1es.

Whe following is a desorlption of the properties of these three systems:

1) The etnyl cellulose-Arochlor 1262 gystem produced strong seals. Tearing bonds were made with aluminum foll, glassine paper, cellophane, and other packaging papers. Bond ing laequers of this system is easily accomplished at $150^{\circ} \mathrm{C}$

To produce tearing bonds these la oquers must contain more than 20\% Arooh 1or 1262. Laoquers containing less than $20 \%$ of the Arochlor resin are non-blooking under tho specifled test conditions. All fomulations of the system passed the flexiblilty requirements. The best oombination of adhesion and blocking characteristios in the system is found in the laoquer containing

$$
\begin{aligned}
& \text { ethyl oellulose } \ldots \ldots-75.0 \% \\
& \text { Aroohlor } 1262 \ldots-\ldots-\infty 25.0 \%
\end{aligned}
$$

The neossary solvent ratio was 5 oo of the 70-30\% tolueneethanol mixture per em. of solids. This laqquer will pase the block test only if the temperature requirement is lowered to 4000 .

Carnauba wax was added to make the laoquer nonblocking at the specifled 5000. The formulation then becomes ethyl cellulose $-\ldots--74.6 \%$ 


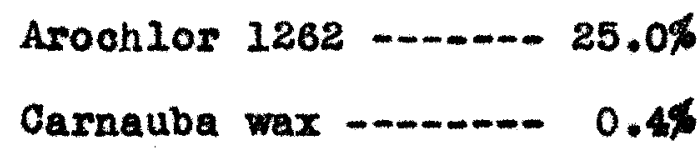

In order to dissolve the wax, it is necessary to heat the laoquer to the bolling polnt of the toluene-ethanol solvent mixture.

The final ethyl oellulose-Arochlor-wex combination seals with tearing bonds, is non-blooking, tranaparent, and rlexible. Table II 11sts the formulations of the systems that were tested and rates the adhesion, blooking, and flexiblitty properties of each.

(2) The system ethyl cellulose-Dow resin 276-V2trioresyl phosphate also gave good results. Seals of tearing bond were made from lacquers of this system to all the materlals 118ted in Table $V$. The blocking reslstanoe developed In this system is greater than that of the Arochlor formulat1on. Since the Dow resin is itself a liquid, all formulations of the system are flexible. Flgurs 14 shows the adhesion, blocking, and compatibility charaoteristios of this system.

A formulation of

$$
\begin{aligned}
& \text { ethyl oellulose - - }-55.0 \% \\
& \text { Dow resin } 276-72---30.0 \% \\
& \text { trloresyl phosphate }-15.0 \%
\end{aligned}
$$

best combined the properties of adhesion and non-blook. A solvent ratio of 4 oo of solvent per gm. solids 1s gufficient to bring this lacquer to the proper viscosity. 
Carnauba wax was added to this system to raise its blocking temperature. With the wax addition the formulation becomes

$$
\begin{aligned}
& \text { ethyl oellulose -.... } 55.0 \% \\
& \text { Dow resin 276-72 …. } 30.0 \% \\
& \text { tricresyl phosphate -- 14.7\% } \\
& \text { carnauba wax ......... } 0.3 \%
\end{aligned}
$$

Th1s laequer will be roferred to as $135-148$.

Samples of HS-148 were subjected to the cold

storage, aging, and maohine tests described earlier. No loss of properties was noted in the films after 24 hours contaot with dry $10 e$ and 30 days in the freezing compartment of an eleotrlo refrigerator. The aging test was run on this formulation for 5 months. No loss in adhesion, non-block, or plexibility was noted.

The cork tippling and package seals made with HS-148 In the Brown and WIIllamson plant were oompared to the same seals made with regular industrial adhesives. In the case of cork tlpping 300 seals were tested. Table VI 11sts the result of this testing. $88 \%$ of these seams were tighter and more durable than the regular seal, $7 \%$ were not as good as the regular seal, but no difference could be deteoted in the remaining 5\%. The fo11-to-foll seams made on the all-metal paokage were rated in comparison wh packages made with the 
regular adhesive. Ifttle or no differenoe could be detected between the seals of HS-148 and those of the regular laoquer. An attempt to substitute Dow Plastiolzer No. 5 for trioresyl phosphate resulted in the following formulation whloh w1L1 be referred to as HS-196:

$$
\begin{aligned}
& \text { ethyl cellulose -......- } 45.0 \% \\
& \text { Dow resin 276-V2 -...-. } 40.0 \% \\
& \text { Dow plasticizer No. } 5 \text {-- 14.7\% } \\
& \text { Carnauba Wax -............ } 0.3 \%
\end{aligned}
$$

Toluene was found to be the best solvent for this terlel. Films of Hs-196 adhere with tearing bonds to the materials 11sted in Table $\nabla$. They are flexiblo and transparent. The carnaube wax addition makes it possible for HS-196 flims to pass the blocking test. Jnder extreme cold, lacquers of this formulation became brittle but did not lose adhesion. An aging test of two months showed no ohange in the properties In tilms of HS-196.

Figure 15 shows the adhesion, bloaking, and compat1bility charaoteristios of thls system. 
TABLE I

Adhesion, Blocking, and Floxiblilty Charaoterlstios of the Formulation of Eaoh System Best Combining The se Propertles.

\begin{tabular}{|c|c|c|c|}
\hline Sys tem & Adhe sion & Blooking & Flexibil1ty \\
\hline $\begin{array}{l}\text { Ethyl oellulose-Dow Plast10- } \\
\text { 1zer No. } 6\end{array}$ & good & poor & good \\
\hline Ethyl Cellulose-Aroohlor 1262 & good & good & good \\
\hline $\begin{array}{l}\text { Ethyl Cellulose-Bakel1te } \\
\text { XR } 14987\end{array}$ & poor & poor & good \\
\hline $\begin{array}{l}\text { Ethyl Cellulose-Nevillac S- } \\
\text { Aroohlor } 1262\end{array}$ & fair & fat $\mathbf{r}$ & good \\
\hline $\begin{array}{l}\text { Ethyl Cellulose-Bakelite 254- } \\
\text { Dow Plastlo1zer No. B }\end{array}$ & poor & good & good \\
\hline $\begin{array}{l}\text { Ethyl Cellulose Super Beoka- } \\
\text { ofte 1001-Dow Plastiolzer } \\
\text { No. } 6\end{array}$ & poor & good & good \\
\hline $\begin{array}{l}\text { Ethyl Cellulose-Trioresyl } \\
\text { Phosphate-Rosin WW }\end{array}$ & ralr & rair & fatr \\
\hline $\begin{array}{l}\text { Bthyl Cellulose-Trioresyl } \\
\text { Phosphate-Staybelite Resin }\end{array}$ & good & poor & $800 d$ \\
\hline $\begin{array}{l}\text { Ethyl Cellulose-Poly Pale } \\
\text { Resin-Bakelite XJ } 15330\end{array}$ & poor & good & falr \\
\hline $\begin{array}{l}\text { Ithyl Cel lulose-Dow Resin } \\
\text { 276-V2-Tricresyl Phosphate }\end{array}$ & 80 od & Bood & $80 \circ$ \\
\hline $\begin{array}{l}\text { Ethyl Cellulose-Dow Resin } \\
\text { 276-V2-Dow Plast1 o1zer No. } 6\end{array}$ & good & good & good \\
\hline
\end{tabular}


TABLE II

Adhosion, Blocking, and Flexibility Charaoteristios of the System Ethyl Cellulose-Aroahlor 1262

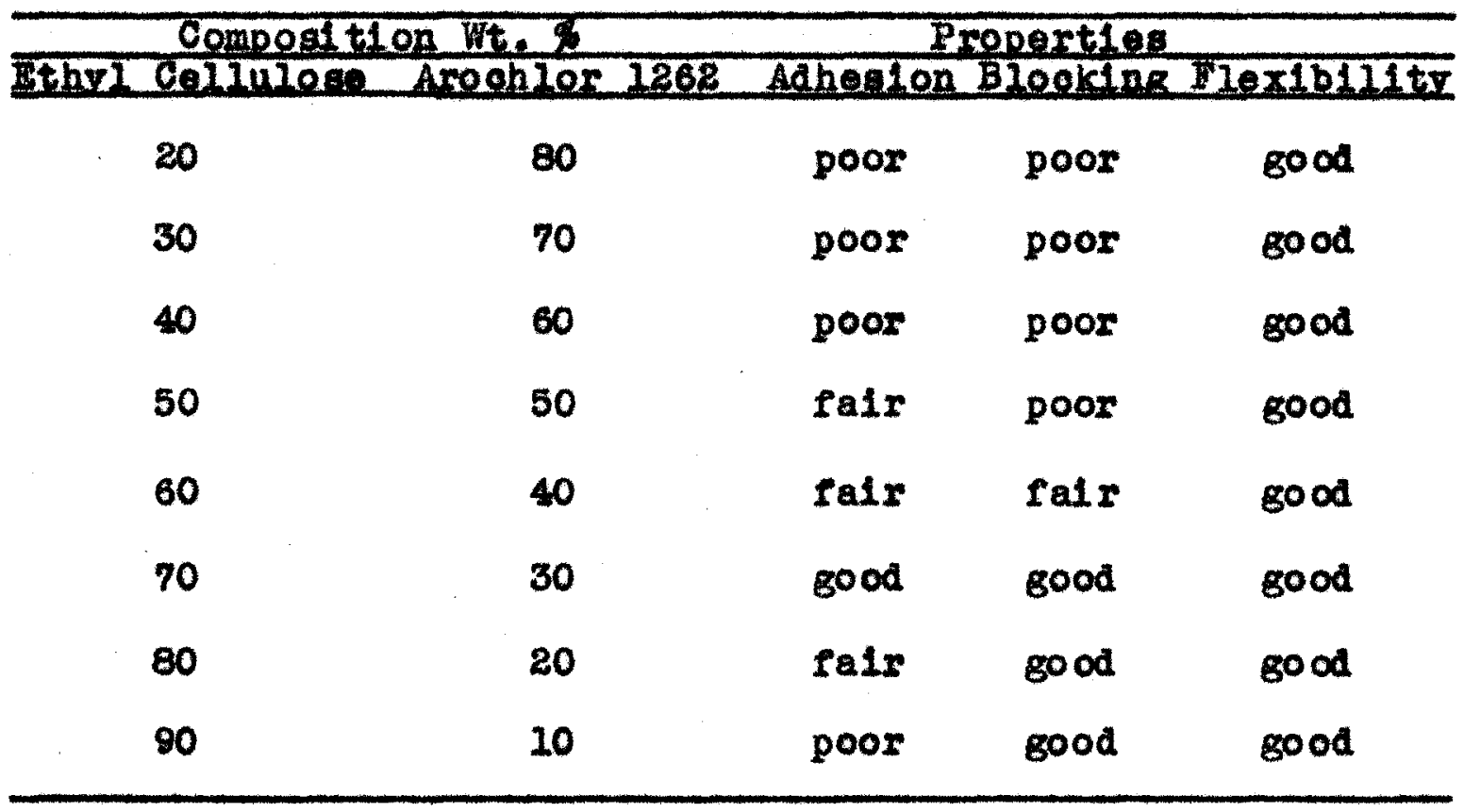


TABLE III

Adheslon, Blooking, and Flexibllity Characteristics of the System Ethyl Cellulose-Dow Plasticlzer No. 6

\begin{tabular}{|c|c|c|c|c|}
\hline \multicolumn{2}{|c|}{ Composition Wt. } & \multicolumn{2}{|c|}{ Propertiles } & \\
\hline 20 & 80 & poor & poor & good \\
\hline 30 & 70 & poor & poor & good \\
\hline 40 & 60 & falr & poor & good \\
\hline 50 & 50 & good & fair & good \\
\hline 60 & 10 & falr & fair & good \\
\hline 70 & 30 & poor & good & good \\
\hline 80 & 20 & poor & good & good \\
\hline 90 & 10 & poor & good & 8000 \\
\hline
\end{tabular}


TABLE IV

Adhesion, Blooking, and Flexiblilty Charaoterlatios of the Syatem Ethyl Cellulose-Bakelite XR 14987

\begin{tabular}{|c|c|c|c|c|}
\hline \multicolumn{2}{|c|}{ 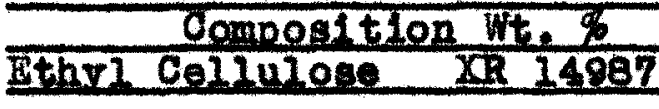 } & \multicolumn{3}{|c|}{$\begin{array}{l}\text { Propertiog } \\
\text { Adheslon Blooking Flexibility }\end{array}$} \\
\hline 20 & 80 & poor & poor & good \\
\hline 30 & 70 & poor & poor & good \\
\hline 40 & 60 & poor & poor & good \\
\hline 50 & 50 & poor & poor & $800 d$ \\
\hline 60 & 40 & poor & rair & good \\
\hline 70 & 30 & poor & rair & good \\
\hline 80 & 20 & poor & good & good \\
\hline 90 & 10 & poor & good & good \\
\hline
\end{tabular}

\section{TABLE V}

Materiala to Which Fonulations HS-148 and HS-196 Were Sealed

\begin{tabular}{lll}
\hline Aluminum Foll & Olass & Olgarette Paper \\
Magnesium Sheeting & Cellulold & Steel and Iron Plate \\
Cellophane & Wood & Low Grade Papers \\
Bond Paper & Cork & Ethyl Cellulose Sheeting \\
Glassine Paper & Cardboard & Vingl Sheoting \\
\hline
\end{tabular}


TABLE VI

Comparison Between Cork TIppling Seans Made W1 th HS-148 and Those Made With the Regular Industrial Adhesire

\begin{tabular}{cccc}
\hline $\begin{array}{l}\text { Better than } \\
\text { reguiar seam }\end{array}$ & $\begin{array}{c}\text { Not as good as } \\
\text { negular seam }\end{array}$ & $\begin{array}{c}\text { No apparent } \\
\text { differenoe }\end{array}$ & Total \\
\hline 264 & 21 & 15 & 300 \\
\hline
\end{tabular}




\section{DISCUSSION}

Three laoquers have been formulated that fulfill the physioal requirement for a heat sealing agent. No reference had been made, however, to toxicity. The problem requirements state that a IIIm to be applied to the paokaging of tood and related products must be free from toxlc effeots. The following is a discussion of the toxlolty present in each of the three proposed laoquer formulations:

(1) The laoquer containing Arochlor 1262 has a marked toxic effect on everything with which it comes in oontaot. The toxio nature of this laoquer is entirely due to the Aroohlor 1262. Aroohlor 1262 has a strong corrosive effect on human tissue. Fxtended oontrot with the heary Ilquid causes deep burns. Fumes of this resin are sharp and aorid. If drawn Into the lunge they cause smarting and coughing.

Laoquers containing such torio onstituents can not be recomended for use in the packaging of foods. Its effeot on human skin make eren the manufacture of suoh la equera quite dangerous.

(2) Leqquer HS-148 contains ethyl cellulose, Dow resin 276-V2, trioresyl phosphate, and carnauba wax. W1th the exoeption of trloresyl phosphate, none of these constituents possess deteotable toxiolty. 
A letter to the Monsanto Chemioal Company of St. Louls, Missourl, conoerning the toxiolty of trioresyl phosphate made by them brought the following reply from Dr. R. E, Kelly, Medical Direotor: "The trioresyl phosphate manufactured by us containg less than two per cent of the or tho isomer. The ortho isomer has been inclted as the toxio element of trieresyl phosphate, but I do not believe it can be sald that even a meta para mixture possesses no toxiofty.

"The advisability of using trioresyl phosphate as a coating to be applled in the food paokaging ind ustry would depend on whether or not this material could be abstracted from the coating by the food. If such a situation could be present we would not advise its use as we think that even a low ortho isomer tricreayl phosphate possesses toxicity."

The Information in Dr. Kelly's letter indicated that, al though containing only $14.7 \%$ trloresyl phosphate, HS-148 possesses a potential toxlofty. Since the lacquer itself is never applied in direot oontaot with rood, it is quite doubtful that this toxic effeot would be felt. The only guarantee of safety, however, would be the aotual testing of this 1acquer in oontact with the food to be paokaged.

(3) HS-196 contains ethyl cellulose, Dow resin 276V2, and Dow plastlolzer No. 5. All these materla ls are products of the Dow Chemioal Company of Midland, Mlohigan. Mr. 
K. D. Bacon of that oompany states that these three materlals are entirely free from toxio1ty. From this information it can be stated that formulation HS-196 has no toxdo effeot and 1s, therefore, sulted to application in the packaging of food and related products. 
CONCTUSIONB 
Two lacquers have been formulated whioh meet the problem specifloations. Both are olear, flexible films whioh rorm tearing bonds with aluminum foll, glassine paper, cellophane, and other packaging papers. Baoh is non-blooking at 50 degrees C. under 1 pal.

$$
\begin{aligned}
& \text { HS-148, composed of } \\
& \text { ethyl cellulose }-.-55.0 \% \\
& \text { Dow resin } 276-\mathrm{V} 2 \ldots-.30 .0 \% \\
& \text { trioresyl phosphate - } 14.7 \% \\
& \text { carnauba wax -...... } 0.3 \%
\end{aligned}
$$

has better adhesion and blocking charaoteristios than has HS-196. For this reason HS-148 is recommended as the best formation for general heat sealing applloatiov.

$$
\begin{aligned}
& \text { HS-186, composed of } \\
& \text { othyl cellulose } \ldots . . .-45.0 \% \\
& \text { Dow resin 276-V2 -... } 40.0 \% \\
& \text { Dow plastiolzer No.5 - } 14.7 \% \\
& \text { carneuba wax -...... } 0.3 \%
\end{aligned}
$$

is free or all toxiclty. For this reason it is recamended for applioation where contact with food produots is unavoldable. 
LITARATURE CITHD 
1. Braude, F., "Adhesires", lat Rdition, Vol. 1, pp. 3, Now York, Ohealoal Publishing Co. (1943)

2. Del Monte, "Technology of Adhesives", lst Ed1tion, Vol. 1. pp. 245, New York Relnhold Publishing Co., 1947

3. Wht tham, G. S., Modern Pulp and Paper Making", lst edition, Fol. 1, pp. 71, New York, Reinhold Publishing Co., 1942

4. Flscher, I. J., Whachee, Wechsahnllohe Storfe und Teohnische Wachsmenge", pp. 10, Verlag Von Theodox Stelnkoptt, Dresdon and Lolpzig (1934)

5. Cordon, R., Modern Paokaging, 8, 50 (1935)

6. Steundinger, German Patent 659,814, May 11, 1938 (Abstrect only)

7. Henk10, Brit1sh Patent 478,299, January 10, 1938

8. Henkle, J, S. 2,164,585, July 4, 1939

9. Bidald and Farre, French Patent 841,836, May 31, 1939 (Abatract only)

10. Nobe1, Brit1sh Patent 576,368, January 1, 1940

11. P1tman, C. I.., Ganadian Patent 395,145, Maroh 11, 1941 (Abatraet only)

12. I. G. Tarben Ohemistry Corp., "Farben Chemlatry", 1at Ed1tion, Vo1. 12, pp. 29-31 (1941)

13. Ryan and Watk1ns, J, S. 2,330,313, September 28, 1943

14. Kaupp 1, T. A., U. S. 2,276,478, Marah 17, 1943

15. Thinlus, K., U. S, 2,284,178 
16. Barrow, W. J., J. S. 2,301,996, November 17, 1943

17. Szware, S., Ganadian Patent 417,155, December 21, 1945 (Abstract only)

18. DeBell, J. M., Britl sh Patent 555,520, August 26, 1943

19. Lelnbaoh, F. S., Modern Packaging, 16, 85 (1943)

20. Binner and Miller, Paper Irade Journal 24, 37 (1944)

21. Collins, W. R., U. S. 2,351,600, June 20, 1944

22. Kooh, W. W., U. S. 2,333,577, Norember 2, 1944

23. Rob1nson, J. E., U. S. 2,361,302, October 24, 1944

24. Bacon, I. S., U. S. 2,361,527, Notober 31, 1944

25. Mack, O., U. 3. 2,349,508, May 23, 1944

26. Rhodes and Wendore, U, S. 2,371,314, March 13, 1945

27. T1llotson, N. E., U. S. 2,373,404, Apr11 10, 1945

28. Jones, A., American Paper Converter, 19, 22 (1945)

29. Thomas, P., Plastios, Chicago Convention Lidition, 3, $80(1945)$

30. Metzler, Plestlos and Resins Industry, 6, 11 (1943)

31. Sm1th, R., Modern Plastios, 24, 5 (1947)

32. Le1nbaoh, F. S., Modern Plast10s, 24, 91 (1947)

33. Jones, A., Industrial Engl neering Chemlstry, 39, 168 (1947)

34. Lelnbach, 7. S., Modern Packaging, 16, 86 (1843)

35. Hof man, H. E., and Re1d, E. W., Graphloal Methods in Laoquer Teohnology, Ind. Eng. Chem. 20, 431 (1928) 
36. Jones, A., "Cellulose Lacquers, Finishes, and Cements", lat kaltion, Vol. 2, pp. 62-74, New York, Lippenoott and Co. (1938)

37. Jones, A., "Cellulose Lacquers, Hinlshes, and Cements", lst Edition, Vol. 1, pp. 357, New York, Lippencott and Co. (1938)

38. Dow Chemical Company, "Ethocel Handbook", Vol, 1, pp. 49, Midiand, Miohigan (1940)

39. Kaess, O., Z. Verpackung, 15, 140 (1947) 
Th1 research was made possible through a followshlp grant by the Dow Chomical Company to the

Unirersity of Lou1sv111e Department of Chemioal Engineering 
APPENDIX 
LATERTALS:

RESINS

Nene

Aroohlor 1262

Bakelite BR 254

Bake 11te XR 14987

Bake11 te XJ 15330

Nerillac $\mathrm{S}$

Poly Pale Resin

Rea1n 276 V2

Rosin W W

Staybelite Resin

Super Beokadte 1001

Trade Name

Dow plastlcizer

No. 5

Dow Plastielzer

No. 6

Plexol DPO

Sant101zer B16

Trioresyl Phosphate
Type

Chlorinated D1phenyl

Phenol10

Phenol10

Modifled Phenolio

Coumerone-Indene

Hydrogenated Rosin sster

Styrene Derivative

Natural Rosin

Natural Rosin sater

Phenolic

\section{PLASTICTZERS}

Chemical Name

Diphenyl Monophosphate

Dimonophenyl Phosphate

Polyethlene Glyool

D1-2-1thylhexoate

Butyl Phthalyl Butyl Glyoollate

Trieresyl Phosphate manufacturer

Monsanto Chem. Co.

Bake 11te Corp.

Bake 11te Corp.

Bake 1ite Corp.

Nev1110 Co.

Hercules Pomder Co.

Dow Chem1oal Co.

Hercules Powder Co.

Heroules Powder Co.

Relchold Chemicals Ino.

Manufacturer

Dow Chemioal Co.

Dow Chem1oal Co.

Carbide Carbon

Chemicals Corp.

Monsanto Chemical Co.

Monsanto Chomical Co. 
VITA 
The author was born in Jackson, M1ss1ssipp1, on Septenber 18, 1924. His Father, W11liam Bla ok Moore, and mother, Ma1 Isom Whitten Moore, were nat1ve to M1saisippi. Both are of Sootoh-Irish anoestry.

Unt1l the age of three, the author 11red in Jackson, Missisaipp1, moving in 1927 to Greenville, South Garolina. He, at four gears, entered a private sohool, transferring to Haymes primary sohool two years later. In 1931 his family returned to Jackson, where he was then entered in Power School. From here he progressed to Bailey Junior High in 1837. After two years in junlor hlgh, the author began his high sohool training in Central High at Jaokson.

The author attended Mississlppl State College in Starksville, Mississippl, following his high school graduation in 1942. His training in Chemioal Ingineering at Mis sissipp1 State oame to an end in 1943 when he was called into the Nary V-12 program at the Univerg1ty of Louisviule. There he continued work toward fulfiling the requirements for the degree of Bachelor of Chemioal Bnglineering. The degree was awarded in February, 1945.

On May 5, 1945, the author was oommissioned Ensign, CEC, USIVR, and was Imediately sent to Manlia, P. I., to jo1n the Thirty-fifth Naval Conatruction Battalion. He was retired to inactive reserve status in July, 1946. 
Mr. Moore was married to Miss Lillian Wolls on Soptember 14, 1946. Mrs. Moore, the daughter of Anne Ramegy Ionglno and John Thomas Wells, was born in Oreenwood, Miss1ssipp1.

In order that he might work toward the degree of Master of Chemieal Inglneering the author re-entered the Bniversity of Loulstille on Ootober 1, 1046. At th1s time he received the Dow Jellowahlp. With the acceptenoe and subsequent publioation of this thesis in September, 1947; he w11l recelve the degree of Uaster of Chemloal Bngineering. 